\title{
Nanotechnology in Wastewater Management: A New Paradigm Towards Wastewater Treatment
}

\author{
Keerti Jain ${ }^{1, * \mathbb{D}}$, Anand S. Patel ${ }^{1}$, Vishwas P. Pardhi ${ }^{1}$ and Swaran Jeet Singh Flora ${ }^{2, * \mathbb{D}}$ \\ 1 Department of Pharmaceutics, National Institute of Pharmaceutical Education and \\ Research (NIPER)—Raebareli, Lucknow 226002, India; aspsidhi1998@gmail.com (A.S.P.); \\ vishwaspardhi678@gmail.com (V.P.P.) \\ 2 Department of Pharmacology and Toxicology, National Institute of Pharmaceutical Education and \\ Research (NIPER)—Raebareli, Lucknow 226002, India \\ * Correspondence: keertijain02@gmail.com or keertijain.02@niperraebareli.edu.in (K.J.); \\ sjsflora@hotmail.com (S.J.S.F.)
}

check for updates

Citation: Jain, K.; Patel, A.S.; Pardhi, V.P.; Flora, S.J.S. Nanotechnology in Wastewater Management: A New Paradigm Towards Wastewater Treatment. Molecules 2021, 26, 1797. https: / / doi.org/10.3390/ molecules 26061797

Academic Editors: Maria

Isabel Capela and

Mohammadreza Kamali

Received: 30 January 2021

Accepted: 11 March 2021

Published: 23 March 2021

Publisher's Note: MDPI stays neutral with regard to jurisdictional claims in published maps and institutional affiliations.

Copyright: (c) 2021 by the authors. Licensee MDPI, Basel, Switzerland. This article is an open access article distributed under the terms and conditions of the Creative Commons Attribution (CC BY) license (https:// creativecommons.org/licenses/by/ $4.0 /)$.

\begin{abstract}
Clean and safe water is a fundamental human need for multi-faceted development of society and a thriving economy. Brisk rises in populations, expanding industrialization, urbanization and extensive agriculture practices have resulted in the generation of wastewater which have not only made the water dirty or polluted, but also deadly. Millions of people die every year due to diseases communicated through consumption of water contaminated by deleterious pathogens. Although various methods for wastewater treatment have been explored in the last few decades but their use is restrained by many limitations including use of chemicals, formation of disinfection by-products (DBPs), time consumption and expensiveness. Nanotechnology, manipulation of matter at a molecular or an atomic level to craft new structures, devices and systems having superior electronic, optical, magnetic, conductive and mechanical properties, is emerging as a promising technology, which has demonstrated remarkable feats in various fields including wastewater treatment. Nanomaterials encompass a high surface to volume ratio, a high sensitivity and reactivity, a high adsorption capacity, and ease of functionalization which makes them suitable for application in wastewater treatment. In this article we have reviewed the techniques being developed for wastewater treatment using nanotechnology based on adsorption and biosorption, nanofiltration, photocatalysis, disinfection and sensing technology. Furthermore, this review also highlights the fate of the nanomaterials in wastewater treatment as well as risks associated with their use.
\end{abstract}

Keywords: wastewater treatment; nanotechnology; adsorption and biosorption; nanofilters; photocatalysis; disinfection; sensors; carbon; metals; zeolites

\section{Introduction}

For survival and development of living beings, many things are required, but no other things could be more important than water. Earth is known as a blue planet as about $70 \%$ of the earth's surface is covered with water. Saline water makes about $97.5 \%$ of the total water, while the remaining $2.5 \%$ is regarded as fresh water and out of this fresh water about $68.9 \%$ of water is in the form of ice, permanent snow, and glaciers. Furthermore, ground water accounts for $30.8 \%$ of fresh water, out of which only $0.3 \%$ is easily accessible [1]. Clean and safe water is a basic asset for a flourishing society as well as a thriving economy [2]. Unfortunately, a rapid increase in population, expanding industrialization, urbanization and extensive agriculture practices are causing continuous deterioration of quality water resources, which is a serious matter of global concern [3-5]. Worldwide, around 1.2 billion populations do not have access to safe drinking water, 2.6 billion people struggle to fulfil basic sanitation, millions of people, particularly children, have lost their lives from diseases communicated through unsafe and polluted water [6,7]. 
Diarrhea caused by the consumption of contaminated water takes the life of approximately 1.8 million children every year [6,8].

Physicochemical or conventional and biological methods to address wastewater treatment include coagulation, flocculation, precipitation, adsorption, ion-exchange, electrodialysis membrane separation, and aerobic, anoxic or anaerobic oxidation methods. However, wastewater treatment through these physicochemical methods often involve chemicals (such as chlorine compounds, ammonia, permanganate, alum, sodium hydroxide, hydrochloric acid, ozone, and ferric salts, coagulation and filtration aids, ion exchange resins and regenerants) and energetically and operationally intensive mechanical methods, and thus requires engineering expertise and infrastructure. Additionally, it has been observed that conventional techniques are not efficient enough to remove toxins, phosphorous, nitrogen, heavy metals completely from contaminated wastewater. Although all these factors rendered them expensive and time consuming, all of them decrease the level of various pollutants to some extent and have their own advantages and disadvantages $[6,7,9,10]$.

Nanotechnology is basically a manipulation of matter at the molecular and atomic levels to craft a new structure, device and system with superior electronic, optical, magnetic, conductive and mechanical properties [11-15]. Nanotechnology is being explored as a promising technology, and has demonstrated remarkable accomplishments in various fields including wastewater treatment. Nanostructures offer unparalleled opportunities to make more effective catalysts and redox active media for wastewater purification, owing to their small size, large surface area, and ease of functionalization. Nanomaterials have been found to be effective in elimination of several pollutants from wastewater such as heavy metals, organic and inorganic solvents, color as well as biological toxins, and pathogens that cause diseases like cholera and typhoid [6].

\section{Wastewater: Sources and Composition}

Wastewater contains several dangerous and harmful materials and it originates from various sources, which includes sewage, industrial and commercial waste, agricultural waste etc., which could be characterized by their physical appearance, chemical composition, and loads of microorganisms [16]. Generally, wastewater comes from normal living processes or in other terms wastewater is any water that has been contaminated by human use $[17,18]$. The major sources of wastewater are domestic wastewater, agricultural waste, industrial waste, and commercial waste [19]. Almost all the major sources need good quality water, particularly industries, but in return a huge volume of contaminated and polluted water is generated and streamed in large water bodies, making them polluted $[20,21]$. Different sources of wastewater are shown in Figure 1.

Wastewater is a complex matrix composed of $99.9 \%$ of water and the remaining $0.1 \%$ includes suspended solids (350-1200 mg/L), organic compounds like body waste (i.e., feces, toilet paper, food waste), dissolved biodegradable organics (i.e., proteins, carbohydrates and lipids), inorganic solids (i.e., sediment soil, salts and metals), and particulate stuff with an chemical oxygen demand of 250-1000 mg/L, several microorganisms (up to $10^{9}$ number $/ \mathrm{mL}$ ), heavy metals, micro-pollutants and nutrients. Almost, $63 \%$ of phosphate compounds have been found to be associated as a soluble fraction in wastewater $[22,23]$. Figure 2 shows the typical wastewater composition. 


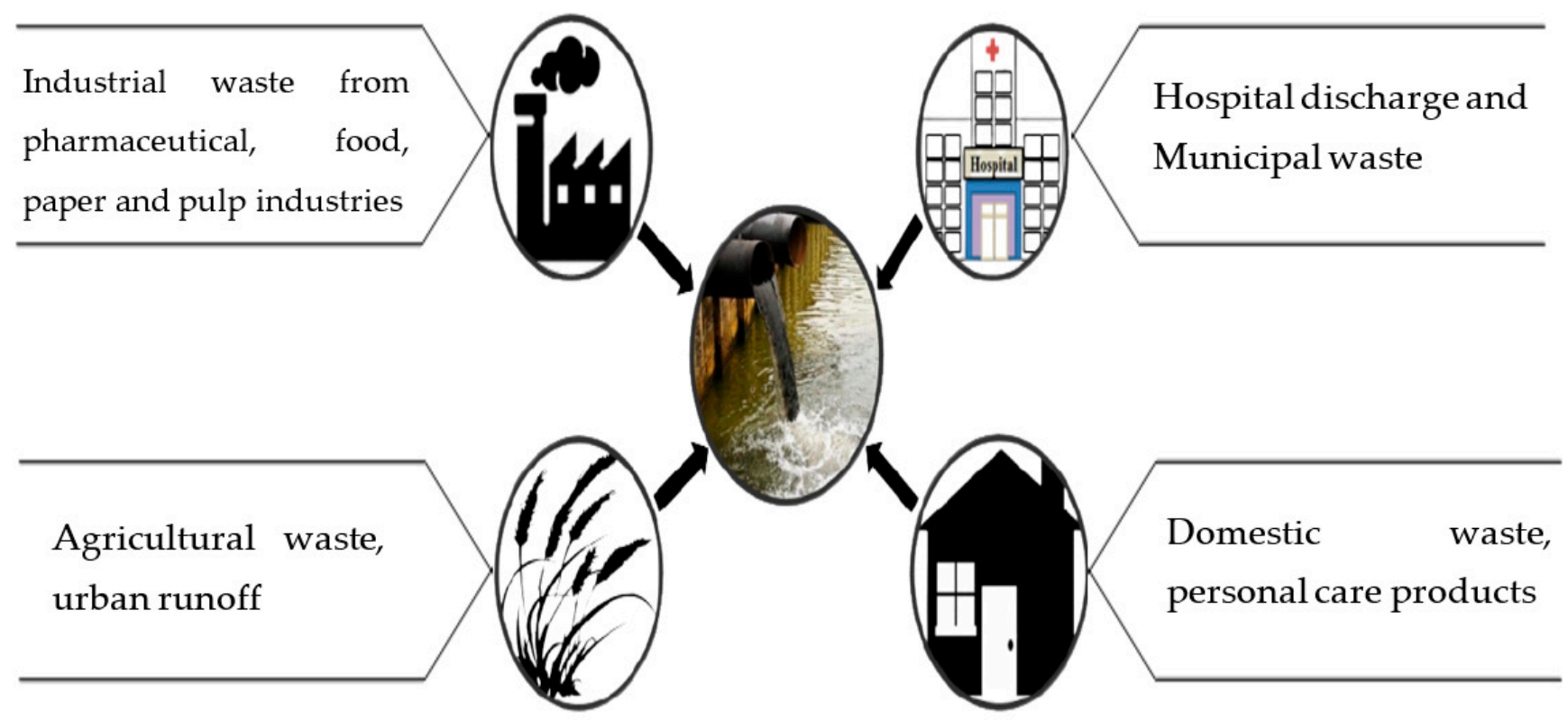

Figure 1. Various sources of wastewater.

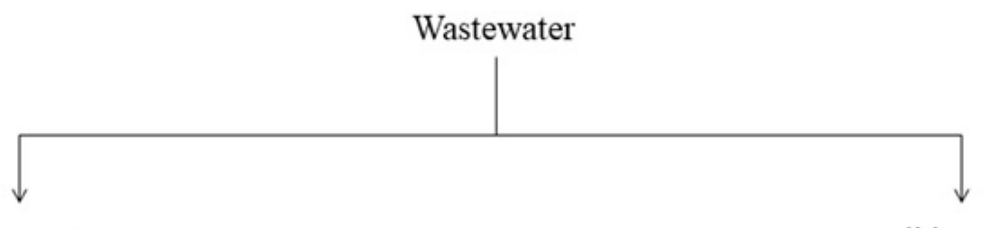

Water $99.09 \%$

Solids $0.10 \%$

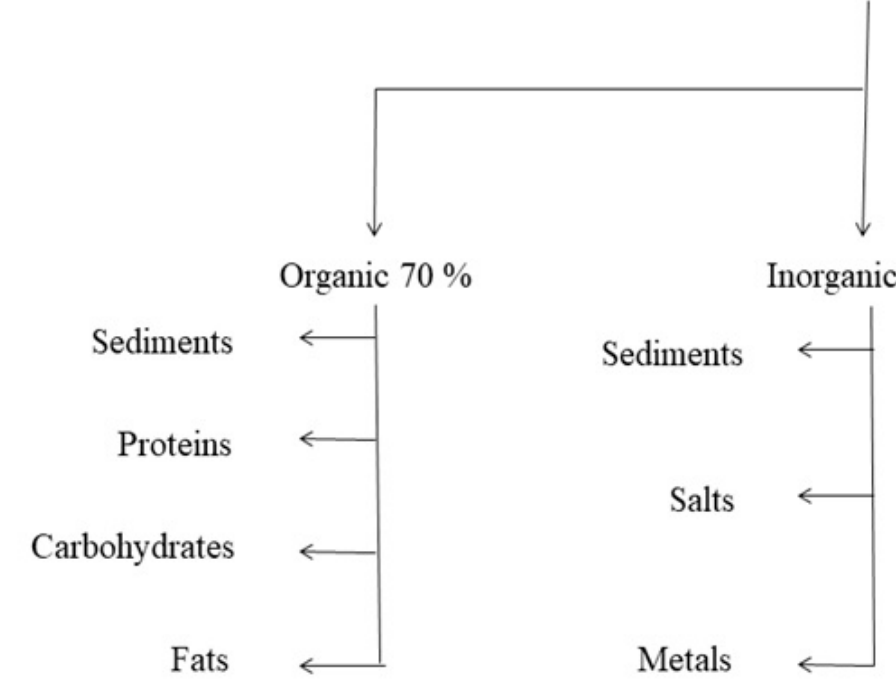

Figure 2. Typical composition of sewage water.

\section{Common Steps in Wastewater Treatment}

In recent years, there has been a rise in industrialization and population growth. In the meantime, the rate of wastewater generation has also grown, which became a serious matter of concern for the environment and ecosystems as well. Accordingly, a proper wastewater treatment is required in order to reuse or return the water to the environment [24]. A process of separation of pollutants or contaminants from wastewater by taking aid of physical or chemical processes before releasing them in the environment is known as wastewater treatment. The aim of wastewater treatment is not only to eradicate contaminants and 
pollutants below the maximum allowed limit, but also to recover micronutrients and water to avoid environmental and human health threats $[25,26]$. The biological wastewater treatment of domestic wastewater can be divided into two main aerobic processes; that is, suspended growth and fixed film processes. Activated sludge is the most widely used suspended growth system, either in the most conventional configuration or as an oxidation ditch or sequential batch reactor, among others. The anaerobic treatment involves anaerobic bacteria that transforms the organic matter present in the wastewater into biogas, which contains large amounts of methane gas and carbon dioxide. The anaerobic treatment is preferred when the dissolved organic concentrations of untreated wastewater are high [21]. The number of stages required to treat wastewater greatly depends on the extent of pollutant to be eliminated and the mechanism of elimination [27].

Preliminary treatment is the first step towards wastewater treatment, which removes large and/or heavy debris. Preliminary treatment typically takes place in two stages: screening followed by grit removal. The screening process removes large floating debris such as rags that account for $\sim 60 \%$ of the debris, paper $\sim 25 \%$ and plastics $\sim 5 \%$, by using screens. Grit removal is the immediate step followed by screening which chiefly removes inorganic particles like gravel, sand and other heavy particulate matters (e.g., bone fragments, coffee grounds and corn kernels) by settling in grit channels [23]. After preliminary treatment, the effluent goes to primary treatment, which predominantly separates the suspended solids via a sedimentation process. Sedimentation takes place in tanks where the effluent is allowed to stay for several hours so that the suspended solids either get settled down or form smut on the top, which is skimmed from the top, and sludge (settled solid on the bottom of the tank) is removed. Primary treatment removes around $40 \%$ of biological oxygen demand (BOD), about $80-90 \%$ of suspended solids, and around 55\% of fecal coliforms [28].

The secondary treatment involves the processing of activated sludge from primary treated water via oxidation ditches, trickling filters or bio-filters, and rotating biological contactors. A combination of the above-mentioned processes in a series is used in the treatment of municipal wastewater having a significant amount of organic materials. To oxidize these organic contaminants, the aid of millions of actively growing microorganisms (single cell), particularly bacteria and protozoa, is taken and they remove organic contaminants from wastewater as a result of their natural metabolic activity [29]. Along with the removal of organic contaminants, secondary treatment also removes some micronutrients such as nitrogen and phosphorous from sewage by the process of nitrification and luxury cell uptake. These micronutrients are usually taken up by algae and fungi for their growth through the process of eutrophication, resulting in diminution of the oxygen level of the water body to which the treated water is discharged [30]. In one study, Yamashita and Ryoko had investigated the efficiency of anoxic bioreactors packed with various combinations of wood and iron along with trickling filters packed with ceramics for the process of nitrification to remove nitrogen and phosphorous from wastewater over a long operation. They found nitrogen and phosphorous removal performance of the bioreactor packed with aspen wood and iron, higher than that of bioreactor packed with cedar chips and iron, during the operational period which was found to continue over a period of 1200 days [31].

Tertiary treatment involves the removal of residual organic, inorganic matter and microorganisms from the effluent of secondary treatment and disinfection of treated sewage by treatment with chlorine, chlorine dioxide, sodium hypochlorite and chloramines, UV (ultra-violet) or ozone radiation before releasing in the environment to make sure that the treated sewage is safe enough to be released [28,30]. It is important to note that the abovementioned stages or processes of wastewater treatment are the basic and traditional ones and the advanced methods based on nanotechnology have been discussed in detail in the following sections. 


\section{Nanotechnology in Wastewater Management}

There are various types of nanomaterials reported, which could be used in the wastewater treatment such as polymeric nanoparticles (NPs), metal NPs, carbon-based nanomaterials, zeolite, self-assembled monolayer on mesoporous supports (SAMMS), biopolymers and many more [32]. Nanotechnology-based pathways, which are being employed for wastewater remediation, are adsorption and biosorption, nanofiltration, photocatalysis, disinfection and pathological control, sensing and monitoring and so on.

\subsection{Adsorption and Biosorption}

Adsorption is an exothermic process and a surface phenomenon which involves the process of the transfer of a phase (a molecule or ion present in either liquid or gaseous bulk) called adsorbate, onto a solid, rarely liquid surface called an adsorbent to form a monomolecular layer on the surface via physicochemical or chemical interactions under specific conditions [33-35]. Biosorption is a kind of adsorption in which biological materials such as certain type of bacteria, algae or fungi act as adsorbents due to their intrinsic property to bind and mount up heavy metals, even from a very dilute aqueous solution or via metabolically mediated (by making use of ATP) or spontaneous physicochemical pathways of uptake (not at the cost of ATP). The process of biosorption principally involves microprecipitation, ion exchange and cell-surface complexation [36-39].

Yang et al. investigated the biosorption of chromium (Cr) (VI) from synthetic wastewater using algal-bacterial aerobic granular sludge. They found that biosorption of $\mathrm{Cr}(\mathrm{VI})$ was highly depended on $\mathrm{pH}$, and observed that maximum $\mathrm{Cr}(\mathrm{VI})$ biosorption capacity of algal-bacterial aerobic granular sludge was $51.0 \mathrm{mg} \mathrm{g}^{-1}$ at $\mathrm{pH}$ 2. $\mathrm{Cr}(\mathrm{VI})$. Removal was predominated by biosorption accompanied with bioreduction. Desorption with $\mathrm{NaHCO}_{3}$ could recover $64-73 \%$ of the adsorbed $\mathrm{Cr}$ and most of this was in the form of $\mathrm{Cr}$ (III). Compared to the conventional bacterial aerobic granular sludge, algal-bacterial aerobic granular sludge demonstrated a higher biosorption capacity and a better granular stability [40]. Similarly, Ding et al. prepared alginate-immobilized Aspergillus niger microsphere (AAM) biosorbent for removal of thorium (Th) ions, particularly $\mathrm{Th}(\mathrm{IV})$, from radioactive wastewater. AAM exhibited a superior $\left(303.95 \mathrm{mg} \cdot \mathrm{g}^{-1}\right)$ biosorption performance at $\mathrm{pH} 6$ and $40{ }^{\circ} \mathrm{C}$. Rapid $\mathrm{Th}(\mathrm{IV})$ enrichment can be achieved in less than $100 \mathrm{~min}$ [41].

\subsubsection{Carbon-based Nano-Adsorbents}

In various fields of science and technology, carbon science has been studied for decades. Nanostructures of carbon are known to have different low-dimension allotropes of carbon such as activated carbon, carbon nanotubes (CNTs), and the $\mathrm{C}_{60}$ family of buckyballs, graphite, and graphene [42]. Carbon nanostructures are widely used as nanoadsorbents for wastewater treatment owing to their abundant availability, cost-effectiveness, high chemical and thermal stabilities, high active surface areas, excellent adsorption capacities, and environmental friendly nature [43]. For years, activated carbon is being used as the most common adsorbent due to their high porosity and large surface area. Although, high cost confines their use, therefore different allotropes of carbon and functionalized carbon are being examined as nanoadsorbents [44].

CNTs are cylindrical, bulky molecules comprised of hybridized carbon atoms in hexagonal assortment, which may be produced by rolling up single or multiple sheets of graphene in order to make single-walled CNTs (SWCNTs), and multiple-walled CNTs (MWCNTs), respectively [45]. Researchers are showing great interest towards CNTs because of their exceptional properties, such as their mechanical flexibility, high specific surface areas, and large pore volumes and that is why CNTs are extensively being exploited in wastewater treatment [46-48]. As adsorbents, these CNTs have shown superior performance over other adsorbents attributed to tunable surface chemistry, which permits surface modifications, a chemically inert nature, hollow structure, high specific surface area, light mass density, high porosity and strong interaction with pollutants [49]. All these properties make them excellent to be utilized in wastewater treatment [50]. Heavy metals 
and ions present in water are a serious peril to the environment as well as human health. Yadav and Srivastava investigated adsorption and desorption of $\mathrm{Mn}^{7+}$ ions by CNTs and observed that CNTs adsorb $\mathrm{Mn}^{7+}$ efficiently and UV-Visible spectrophotometric analysis revealed that CNTs brought down its concentration from $150 \mathrm{ppm}$ to $3 \mathrm{ppm}$. They have used laboratory grade $\mathrm{KMnO}_{4}$ as a source of $\mathrm{Mn}^{7+}$ ions [51].

Demand of pharmaceutical products has grown a lot as a result of population growth and widespread illness. Antibiotics are one of the most widely consumed pharmaceutical product and thus their discharge in the surrounding ecosystem has also increased. Such products, when consumed by humans or other living organisms, cause serious health issues. Kariim et al. synthesized MWCNTs adsorbent by making use of activated carbon derived from wood sawdust, and doped it with nickel-ferrites (Ni-Fe) for the sorption of metronidazole and levofloxacin from pharmaceutical wastewater. The surface morphological analysis revealed the surface area of pure activated carbon and Ni-Fe supported activated carbon CNTs, which was 840.38 and $650.45 \mathrm{~m}^{2} / \mathrm{g}$, respectively. Results from the adsorption process demonstrated a high adsorption capacity of developed MWCNTs for metronidazole and levofloxacin [52]. Zhao and coworkers prepared magnetic MWCNTs (MMWCNTs) that possess the property of both magnetic NPs and CNTs for the removal of tetracycline (TC). The prepared MMWCNTs exhibited the size of 10-50 nm, magnetic separability $(10.8 \mathrm{emu} / \mathrm{g})$, and high adsorption capacity $(q m=494.91 \mathrm{mg} / \mathrm{g}$, $308 \mathrm{~K})$. MMWCNTs showed $>80 \%$ efficiency in adsorptive removal of TC in the $\mathrm{pH}$ range of 2-10, when the TC concentration was less than $80 \mathrm{mg} \mathrm{L}^{-1}$, as determined in batch experiments including adsorption kinetics, adsorption isotherms, and the effect of the initial $\mathrm{pH}$ on TC adsorption by the MMWCNTs. The well-fitted Langmuir isotherm and pseudo-second-order dynamic adsorption model indicated that the adsorption of TC onto MMWCNTs principally involved chemical and monolayer adsorption [53]. Similarly, Yang and coworkers developed surface oxidized nano-cobalt magnetic nanomaterial embedded with nitrogen-doped CNTs $(\mathrm{Co} @ \mathrm{CoO} / \mathrm{NC})$ for effective adsorption of TC and rhodamine B (RhB). The optimized $\mathrm{Co} @ \mathrm{CoO} / \mathrm{NC}$ showed an excellent adsorption capacity for both $\mathrm{RhB}\left(679.56 \mathrm{mg} \cdot \mathrm{g}^{-1}\right)$ and TC (385.60 $\left.\mathrm{mg} \cdot \mathrm{g}^{-1}\right)$. Being a recyclable and reusable magnetic adsorbent, Co@CoO/NC maintained $75 \%$ and $84 \%$ of adsorption capacities for TC and RhB, respectively, after four repetitions [54].

In 2017, Bankole et al. put an effort to make purified CNTs functionalized with polymers as a nanoadsorbent to remove chemical oxygen demand (COD) from wastewater coming from the electroplating industry. Various polymers, such as amino polyethylene glycol (a@PEG), polyhydroxylbutyrate (PHB), purified CNTs (P-CNT), and amino polyethylene glycol with polyhydroxylbutyrate (a@PEG-PHB) were used to functionalize the prepared MWCNTs. Each of the functionalized MWCNTs was allowed to equilibrate for the time of $70 \mathrm{~min}$ and then evaluated for an order of maximum COD removal and the order was a@PEG-CNTs $(99.68 \%)>$ PHB-CNTs $(97.89 \%)>$ P-CNTs $(96.34 \%)>$ a@PEG-PHB-CNTs $(95.42 \%)$. Sorption equilibrium data were best described by Freudlich isotherm with the correlation coefficient of $R^{2}>0.92$ than Langmuir isotherm. The adsorption kinetics for COD removal from wastewater coming from electroplating industry fitted best to the pseudo-second-order model with rate constant within the range of $4 \times 10^{-5}$ to $1 \times 10^{-4}\left(\mathrm{~g} \cdot \mathrm{mg}^{-1} \mathrm{~min}^{-1}\right)$ [55].

Graphene is a two-dimensional material composed of $\mathrm{sp}^{2}$ hybridized carbon atoms compiled in a hexagonal assortment and exhibits ambipolar electric field effects, classical thermal conductivity and quantum hall effects at room temperature, and possesses high surface area and porosity, which makes it an excellent candidate to adsorb several gases like methane, hydrogen, and carbon dioxide. A high surface area, increased active sites, huge delocalized $\pi$-electron systems, and good chemical stability render it suitable to be utilized as an adsorbent for wastewater handling (Figure 3). Properties of this material can be modulated by altering the layer's number and stacking [56,57]. Graphene oxide (GO) is a single monomolecular layer of graphite with a variety of oxygen holding functionalities such as hydroxyl, carboxyl, carbonyl, and epoxide groups [58]. Currently, GO, along with magnetic particles, has gained considerable attention as an adsorbent for wastewater 
treatment because of its simple design, lower sensitivity, low cost and ease of operation towards the toxic pollutants $[59,60]$. Chen et al. envisaged the preparation of aerogel (AG) of GO/aminated lignin (GO/AL-AG) for adsorption of malachite green (MG) dye in wastewater and compared the adsorption capacity at different aerogels dosage, $\mathrm{pH}$, contact time and reaction temperatures. The maximum adsorption capacity and efficiency of prepared GO/AL-AG was revealed by experimental results and was found to be $113.5 \mathrm{mg} / \mathrm{g}$ and $91.72 \%$ under the optimal conditions. The adsorption performance of GO/AL-AG was enhanced significantly in comparison with other AG in the experiment and this was attributed to the synergy between the carboxyl group present over the surface of GO and the amine of aminated lignin. The adsorption efficiency of the GO/AL-AG was about $90 \%$ within 5 cycles of adsorption-desorption [61]. Similarly, Bu et al. developed GO functionalized by thiosemicarbazide (TSC) (GO-TSC) as an adsorbent material for efficient removal of methylene blue (MB) from wastewater. The GO, and GO-TSC had high stability with maximum adsorption capacity of 196.8, and $596.642 \mathrm{mg} / \mathrm{g}$, respectively [62]. Zheng and co-workers prepared hydrogel of GO decorated with silver nanoparticles (Ag NPs) followed by integration with a porphyrin complex as a wastewater remediation technique for adsorption of dyes present in wastewater. Hydrogels were modified with different porphyrin complexes and were evaluated for their adsorption capacity and it was found that tetraphenylporphyrin-modified hydrogel exhibited the highest adsorption capacity (130.37 mg/g) for MB [63]. Recently, Sirajudheen et al. fabricated a hydrocomposite (HCP) of GO supported by a biopolymer, namely chitosan (CS) (GO/CS-HCP) for the efficient removal of organic pollutants from wastewater. The fabricated GO/CS-HCP showed the maximum adsorption capacity for Congo Red (CR) $(43.06 \mathrm{mg} / \mathrm{g}$ ) followed by Acid Red 1 (AR1) (41.32 mg/g) and reactive Red 2 (RR2) (40.03 mg/g) dyes in wastewater. Enhanced adsorption was observed at $\mathrm{pH} 2$ and the removal efficiency decreased with an increase in the $\mathrm{pH}$. Prepared GO/CS-HCP showed an ideal desorption, with more than a $65 \%$ regeneration ability in the $0.1 \mathrm{M} \mathrm{NaOH}$ solution [64].

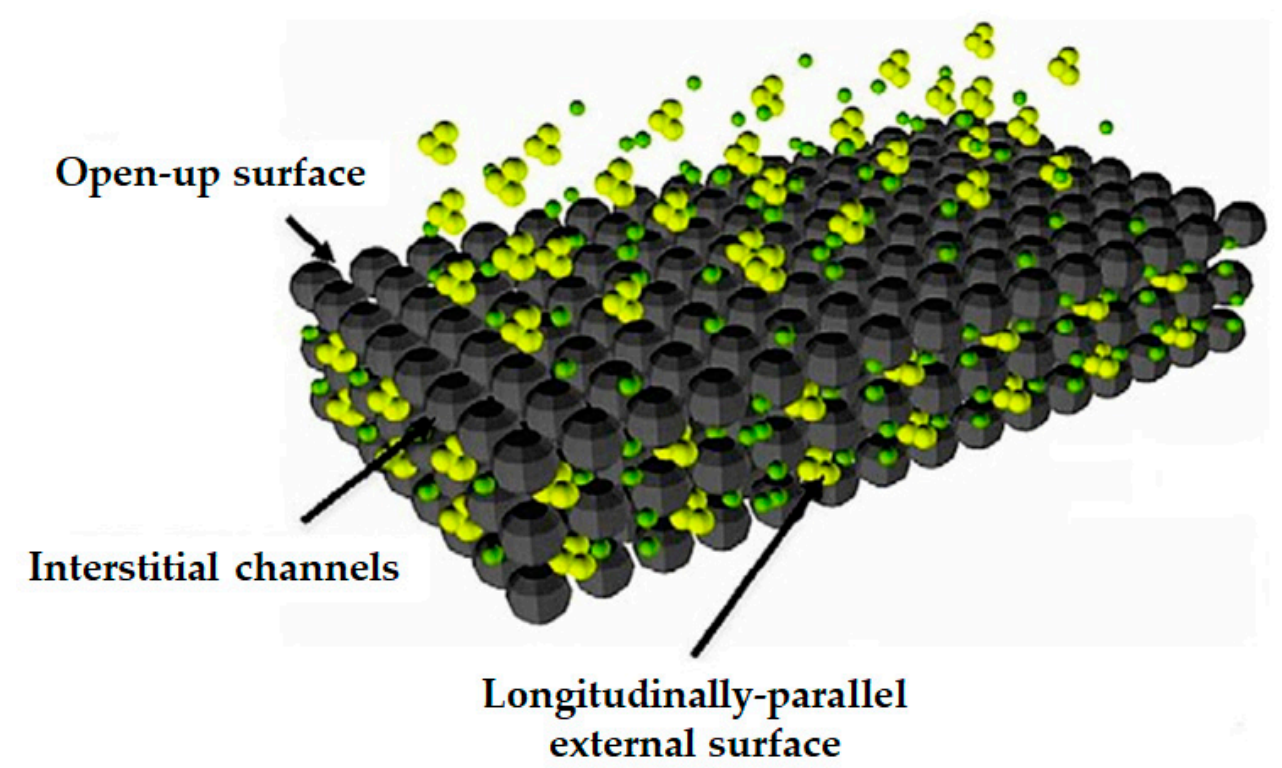

Figure 3. Graphical representation of structure and absorption sites of graphene sheets (Reproduced with permission from [65]).

\subsubsection{Metal based Nanoadsorbents}

Currently, metal-based nanomaterials as adsorbents are catching the eyes of researchers [66]. Nanometals and their oxides such as $\mathrm{Fe}_{3} \mathrm{O}_{4}$ [67], $\mathrm{TiO}_{2}$ [68], $\mathrm{MnO}_{2}$ [69], $\mathrm{MgO}$ [70], $\mathrm{ZnO}$ [71] and $\mathrm{CdO}$ [72] are extensively used to remove heavy metals, ions and 
dyes from wastewater [73]. Nanometal oxides are considered more effective adsorbent as compared to activated carbon when removal of heavy metals and radioactive metals are concerned. Additionally, their small size and large surface area offers a small intraparticle diffusion distance which can be compressed without altering their surface area. The sorption process is mainly governed by the complexation between dissolved metals and the oxygen in metal oxides [74,75].

Wastewater coming from oil refinery contains a variety of ions and metals such as calcium $\left(\mathrm{Ca}^{2+}\right)$ and copper $\left(\mathrm{Cu}^{2+}\right)$. To remove such metals and ions, He et al. prepared reusable nanoadsorbents based on $\mathrm{Fe}_{3} \mathrm{O}_{4} / \mathrm{GO}-\mathrm{COOH}$ by the magnetization and carboxylation of GO. The nanoadsorbents showed $78.4 \%$ and $51 \%$ percent removal of $\mathrm{Ca}^{2+}$ and $\mathrm{Cu}^{2+}$ respectively, at $60 \mathrm{~min}$. The nanoadsorbent retained high recovery rates $\left(82.1 \%\right.$ for $\mathrm{Ca}^{2+}$ and $91.8 \%$ for $\left.\mathrm{Cu}^{2+}\right)$ and removal percentages $\left(72.3 \%\right.$ for $\mathrm{Ca}^{2+}$ and $49.33 \%$ for $\left.\mathrm{Cu}^{2+}\right)$ after five adsorption-desorption cycles [76].

Peralta et al. developed magnetic nanoadsorbents based on silica and evaluated its potential for the elimination of organic pollutants such as contaminants of emerging concern (CECs), polyaromatic hydrocarbons (PAHCs), and aliphatic hydrocarbons (AHCs). The preparation process included the covering of magnetic iron oxide NPs with a hybrid shell consisting of silica and 3-(trimethoxysilyl)propyl-octadecyldimethyl-ammonium chloride (3-TPODAC) as a structure-directing agent. The prepared magnetic mesostructured silica NPs (MMSSNPs) were further modified by means of trimethoxyphenylsilane, to get nanoadsorbents functionalized with phenyl (MMSSNPs-ph). Both the materials were characterized and evaluated for batch sorption tests with single and a mixture of contaminants, and the results revealed that MMSSNPs-ph is more proficient for the adsorption of PAHCs and AHCs. The presence of phenyl and 3-TPODAC moieties on the mesostructured silica scaffolds was found to be a key factor in obtaining high PAHCs uptake from aqueous media. The prepared MMSSNPs-ph was also tested against CECs such as carbamazepine, diclofenac, and ibuprofen and the result showed that although MMSSNPs had better adsorption capacities of CECs, MMSSNPs-ph attained high ibuprofen and diclofenac uptakes [77].

Sadak., et al. fabricated polyacrylic acid (PAA) conjugated ferric oxide $\left(\mathrm{Fe}_{3} \mathrm{O}_{4}\right)$ magnetic NPs (MNPs), which were further functionalized with CR azo dye (PAA-CR/MNPs). This PAA-CR/MNPs system showed a binding affinity for various cations such as $\mathrm{Fe}^{2+}$, $\mathrm{Fe}^{3+}, \mathrm{Cd}^{2+}, \mathrm{Cu}^{2+}$, and $\mathrm{Pb}^{2+}$. Heavy metal removal efficiency of PAA-CR/MNPs was investigated at various $\mathrm{pHs}$, temperatures, reaction conditions, and times with a special emphasis on $\mathrm{Pb}^{2+}$. The removal efficiency and adsorption capacity of PAA-CR/MNPs for $\mathrm{Pb}^{2+}$ were found to be maximal at $6.5 \mathrm{pH}$ and $45 \mathrm{~min}$ of reaction time, and the $\mathrm{Pb}^{2+}$ adsorption kinetics were best fitted to a pseudo second-order model [78].

Arshadi et al. synthesized an adsorbent based on sineguelas waste (S-NaOH) from agriculture biomass, further decorated with nanoscale zerovalent iron particles (NZVIPs). The fabricated system was subjected for the investigation of adsorption/reduction of inorganic pollutant such as $\mathrm{Pb}^{2+}$ ions. The NZVIPs showed good dispersion (ca.10-70 nm) over the surface of sineguelas waste. The fabricated system had a feasible and spontaneous adsorption profile for $\mathrm{Pb}^{2+}$ [79]. Jethave and coworkers developed an efficient nanoadsorbent that consisted of zinc-aluminium oxide NPs doped with lead (LD/Zn-AlO/NPs) for adsorption of anionic dyes such as methyl orange (MO). The MO removal efficiency of $\mathrm{LD} / \mathrm{Zn}-\mathrm{AlO} / \mathrm{NPs}$ reached $99.60 \%$ after $30 \mathrm{~min}$. The spontaneous and exothermic nature of adsorption was indicated by thermodynamic parameters. LD/Zn-AlO/NPs showed a maximum adsorption capacity of $200 \mathrm{mg} / \mathrm{g}$ for $\mathrm{MO}$ in a single component system [80].

\subsubsection{Polymer-Based Nanoadsorbents}

Over the last several years, extensive research has been done on polymer nano composites for the improvement of environmental sustainability and for wastewater treatment. It offers high surface area for fast decontamination, improved processability, remarkable stability, improved processability, cost effectiveness, selectivity to eliminate different pol- 
lutants in wastewater [81,82]. Cost-effective and commonly used polymeric adsorbents include polysaccharides, namely CS cyclodextrin, nano-magnetic polymers, covalent organic polymers, extracellular polymeric substances etc. [83,84] Nanocellulosics, which are derived from cellulose, possess the advantages of being nontoxic, ubiquitous, excellent adsorbents, and have an ease of surface modification, rendering them suitable for wastewater remediation [85]. Recently, preparation of lignin-derived nanomaterials have been introduced, and have demonstrated remarkable potential for water/wastewater treatment. They have been found effective in the catalytic degradation of dyes, nitroarenes, and the removal of heavy metals [86].

Abdi and Abedini developed a metal organic framework adsorbent of zeolitic imidazolate framework (ZIF) based on polymeric nanocomposite beads, namely polyether sulfone (PES), for the efficient removal of Malachite green (MG) from wastewater. The influence of various parameters such as $\mathrm{pH}$, adsorbent dosage, and initial MG concentration were examined on the developed PES-ZIF-8/ZIF-67, as well as PES beads alone. The result showed that PES beads alone had negligible adsorption, whereas PES-ZIF-8/ZIF-67 had an adsorption capacity of $613.2 \mathrm{mg} / \mathrm{g}$, with an MG removal efficiency of $99.2 \%$. The adsorption mechanism was attributed to the aromatic-aromatic interaction ( $\pi-\pi$ stacking) among the rings of MG dye and imidazole ligand [87].

Chen and coworkers fabricated bi-functionalized $\beta$-cyclodextrin $(\beta-C D)$ and polyethyleneimine (PEI) magnetic nanoadsorbents $\left(\beta-\mathrm{CD} / \mathrm{PEI}-\mathrm{Fe}_{3} \mathrm{O}_{4}\right)$ in order to capture $\mathrm{MO}$ and $\mathrm{Pb}^{2+}$ simultaneously from wastewater with spatially separated sorption sites. In the constructed system, N-bearing groups of PEI, with a positive charge and cavities of $\beta-C D$, were thought to be principally responsible for $\mathrm{MO}$ removal via electrostatic attraction and host-guest inclusion, respectively. The edges of $\beta-C D$ with oxygen bearing groups and free amino moieties present on the PEI, acted as active sites for the efficient uptake of $\mathrm{Pb}^{2+}$ from wastewater [88]. Moharrami and Motamedi constructed a nanocomposite hydrogel of biological origin by making use of starch-grafted copolymers of 2-acrylamido-2 methyl propane sulfonate and acrylic acid $\{$ S-g-(AMPS-co-AA) $\}$ with the further addition of cellulose nanocrystals functionalized with magnetite (M-CNCs) for adsorption of cationic dyes such as crystal violet (CV) and MB. The fabricated system showed an adsorption capacity of $2500.0 \mathrm{mg} / \mathrm{g}$ and $1428.6 \mathrm{mg} / \mathrm{g}$ for CV and MB, respectively [89].

Priya et al. envisaged the preparation of nanoadsorbents based on iron-aluminum (Fe-Al) layered dual hydroxide/reduced $\mathrm{GO}(\mathrm{rGO})$ coated with sodium alginate $(\mathrm{SA})$ (FAH-rGO/SA) for removal of arsenic (As). The prepared FAH-rGO/SA-4, FAH- rGO -/SA-1 and FAH-rGO were evaluated for maximum adsorption capacity, which was found to be $190.84,151.29$ and $115.39 \mathrm{mg} / \mathrm{g}$, respectively. The overall results demonstrated a high removal efficiency ( $>98 \%$ ) of FAH-rGO for As (V) and this was attributed to a high weight percentage of SA [90]. Oilfield-produced water has a high salinity due to the presence of metal ions such as $\mathrm{Ca}^{2+}$ and $\mathrm{Mg}^{2+}$. To address this issue, He and coworkers made nanoadsorbents composed of poly (ethylene glycol) (PEG), aminated $\mathrm{GO}\left(\mathrm{NH}_{2}-\mathrm{GO}\right)$, magnetic $\mathrm{Fe}_{3} \mathrm{O}_{4} \mathrm{NPs}\left(\mathrm{PEG} / \mathrm{Fe}_{3} \mathrm{O}_{4} / \mathrm{NH}_{2}-\mathrm{GO}\right)$. The prepared PEG $/ \mathrm{Fe}_{3} \mathrm{O}_{4} / \mathrm{NH}_{2}-\mathrm{GO}$ system showed $69.8 \%$ and $61.1 \%$ removal ratios at $10 \mathrm{~min}$ for $\mathrm{Ca}^{2+}$ and $\mathrm{Mg}^{2+}$, respectively. Overall results indicated its reusability and stability for oilfield wastewater treatment [91].

\subsubsection{Zeolites}

Zeolites are three-dimensional, crystalline microporous materials, having well-defined structures of voids and conduits of distinct size, which is easily accessible through pores of well-defined molecular dimensions that hold aluminum, silicon and oxygen in their normal framework [92-94]. Zeolites are found naturally as silicate minerals and can also be prepared synthetically as magnetically modified zeolite, and bio-zeolite, etc. [95] Presently, zeolitic nanomaterials as adsorbents have attracted considerable attention in environmental applications due to their stability in water, their low cost of production, high surface area, selectivity and compatibility with the natural environment [96-98]. So far, numerous studies have confirmed their extraordinary performance for the removal of metal cations 
from wastewater [99]. Zeolite is found to possess numerous research applications in industries, its adsorbent property is most explored due to their ability to regenerate and reuse, which renders them suitable candidates for wastewater treatment $[100,101]$. Zhao et al. prepared cubic $\mathrm{NaA}$ zeolite, which is one of microporous crystalline aluminosilicate zeolite composed of $\mathrm{Na}_{2} \mathrm{O} / \mathrm{Al}_{2} \mathrm{O}_{3}$. It is obtained from natural halloysite minerals by means of nanotubular structures as a source material for adsorption of ammonium ions $\left(\mathrm{NH}_{4}{ }^{+}\right)$ from wastewaters. The maximum adsorption capacity of prepared NaA zeolite for $\mathrm{NH}_{4}{ }^{+}$ ions was found to be $44.3 \mathrm{mg} / \mathrm{g}$. The constructed adsorbent system showed reusability and demonstrated a potential application in the elimination of $\mathrm{NH}_{4}{ }^{+}$pollutants from wastewater [98].

Bandpi and coworkers fabricated an adsorbent based on natural zeolite (NZ) coated with $\mathrm{Fe}_{3} \mathrm{O}_{4}$ (CNZ) nanoparticles for cephalexin (CEX) removal from aqueous solution. The maximum CEX removal efficiency for CNZ, and NZ were found to be $93 \%$ and $28 \%$, respectively [102]. Similarly, Samarghandi et al. fabricated manganese oxide NPs coated with NZ adsorbents for CEX removal form aqueous solution. The evaluated maximum CEX removal efficiency was $89 \%$ and $28 \%$ for CNZ and NZ, respectively at the pH 7 [103]. Esmaili and Saremnia developed NaA zeolite NPs (NaA-z@NPs) from the husk of Hordeum vulgare $L$. for adsorption of total petroleum hydrocarbon (TPH). TPH removal efficiency of NaA-z@NPs at optimal conditions in both batch and continuous systems was observed to be $92.3 \%$ and $87.4 \%$, respectively [94].

Gugushe et al. synthesized a nanocomposite of MMWCNTs further coated with zeolite $\left(\mathrm{Fe}_{3} \mathrm{O}_{4}\right.$-MWCNTs/Zeolite) for adsorption of $\mathrm{Pb}$ and thallium (TI) in complex environmental samples. The synthesized $\mathrm{Fe}_{3} \mathrm{O}_{4}$-MMWCNTs/Zeolite was utilized as an adsorbent in ultrasonic-assisted magnetic solid phase extraction for $\mathrm{Pb}$ and TI, which showed maximum adsorption capacity of 37.8 and $44.5 \mathrm{mg} \cdot \mathrm{g}^{-1}$, respectively [104]. Nyankson et al. fabricated zeolite and zeolite nanocomposite (Zeolite- $\mathrm{Fe}_{3} \mathrm{O}_{4} @ \mathrm{NC}$ ) for adsorption of organic molecules such as MB from solution. The synthesized Zeolite- $\mathrm{Fe}_{3} \mathrm{O}_{4} @ \mathrm{NC}$ was examined for its potential to adsorb MB from solution by taking aid of UV-visible and kinetic and equilibrium isotherm models. The maximum adsorption capacity and efficiency of $\mathrm{Zeo}-\mathrm{Fe}_{3} \mathrm{O}_{4} @ \mathrm{NC}$ was $2.57 \mathrm{mg} / \mathrm{g}$ and $97.5 \%$, respectively, at $25^{\circ} \mathrm{C}$ and after regeneration, the maximum adsorption efficiency at a $\mathrm{pH}$ of 7 was found to be $82.6 \%$ [105].

\subsection{Nanofilters}

Water filtration is the process of stripping or lowering down the concentration of particulate matter, such as suspended particles, microorganisms as well as other detrimental biological and chemical contaminants from contaminated or polluted water to make safe and clean water for drinking, pharmaceutical and medical applications [106]. Membrane technology has gained considerable attention in recent years and the most important advancement in membrane technology is nanofiltration (NF) membrane. As the name itself suggests, NF membranes have a molecular weight cut-off (MWCO) for uncharged particles in the nanometer range [107]. NF membranes are relatively recent and are the most preferably used method for drinking water and wastewater treatment [108]. NF is a pressure-driven membrane process that lies between ultrafiltration (UF) and reverse osmosis (RO), with a pressure between 5-20 bars and a pore size between 0.5 and $2.0 \mathrm{~nm}$ characterized by a high rejection of divalent or higher-valent ions, a low rejection of monovalent ions, and high flux and low energy consumption compared to $\mathrm{RO}$, and a high rejection compared to UF [109-113]. It is quite a recent advancement in membrane technology and it can be aqueous or non-aqueous. NF is one of the most significant and widely employed techniques in the field of wastewater treatment attributed to its exclusive filtration mechanism and the availability of a variety of membranes. NF is appropriate to filter out more or less all organic and inorganic contaminants, including quite a lot of harmful microbes from wastewater [114-116]. NF membranes are highly flexible, costeffective and easy to produce. Two types of NF membranes are most commonly used, including polymeric membranes and ceramic membranes. The polymeric membranes 
display a short lifetime due to their inferior chemical resistance and a high fouling rate [117]. On the other hand, ceramic membranes have higher mechanical, chemical and thermal stabilities [118].

Mostafavi et al. fabricated an NF based on CNTs for the removal of MS2 virus from water. The MS2 virus is a member of the family related to bacterial viruses which infects the bacterium Escherichia coli and other members of the Enterobacteriaceae family. The NF was characterized for its porosity and surface morphology and then evaluated for MS2 virus removal efficiency. The result demonstrated high removal efficiency at 8-11 pressure bars [119]. Similarly, Parham et al. fabricated a filter based on CNT-ceramic composite for yeast filtration. The fabricated filter demonstrated high $(98 \%)$ filtration efficiency for yeast, and almost a $100 \%$ removal efficiency for heavy metal ions from water [120]. Han and coworkers prepared an NF membrane on the mesoporous substrate for water purification. The fabricated filtration membrane had a thickness of 22-53 $\mathrm{nm}$ and demonstrated an efficient retention for organic dye present in the water. However, the moderate retention was found for ionic substances [121]. Similarly, Nair et al. made a submicrometer-thick NF membranes that displayed an exceptionally high impermeability to any kind of vapors, gases and liquids, excluding water [122].

\subsection{Photocatalysis}

The term "Photocatalysis" comprises two Greek words. "Photo" means "light" and "catalysis" means any substance that alters the rate of a chemical reaction without being involved in the reaction. Therefore, photocatalysis can be defined as a light-induced reaction driven and accelerated by a catalyst [123]. In other words, photocatalysis involves a solid material (photocatalyst) that absorbs light (photons) and induces a chemical reaction [124]. Photocatalysis is one of the Advanced Oxidation Processes (AOPs) that involves in-situ production of extremely potent chemical oxidants with the aid of Fenton's reagent, hydrogen peroxide $\left(\mathrm{H}_{2} \mathrm{O}_{2}\right)$, UV light, ozone $\left(\mathrm{O}_{3}\right)$ or a catalyst. The produced hydroxyl radicals $(\cdot \mathrm{OH})$ are strong enough to oxidize headstrong organic compounds $[125,126]$. AOPs are well-known methods for removal of CECs from wastewater effluent. Photocatalysis has extensively been studied by the scientific community for wastewater treatment, because of its ability to break down an ample range of organic materials, estrogens, dyes, organic acids, pesticides crude oil, microbes (counting viruses and chlorine resistant organisms), some inorganic molecules such as nitrous oxides and when combined with filtration or precipitation, it can also be used to remove metals (i.e., mercury) present in wastewater $[127,128]$. The nanomaterials display a different response compared to bulk materials, owing to their superior surface, mechanical, chemical, electrical, magnetic and optical properties, and distinct quantum effects and hence nanomaterials as a photocatalyst have recently gained great interest of researchers [129-131] [Figure 4].

Photocatalysis is a surface phenomenon and the mechanism associated involves five basic steps [132-134]:

- Diffusion of reactants/pollutants to the surface of photocatalyst

- Adsorption of reactants/pollutants on the surface of photocatalyst

- Reaction of adsorbed reactants/pollutants

- Desorption of products from the surface

- Removal/diffusion of products from interface 


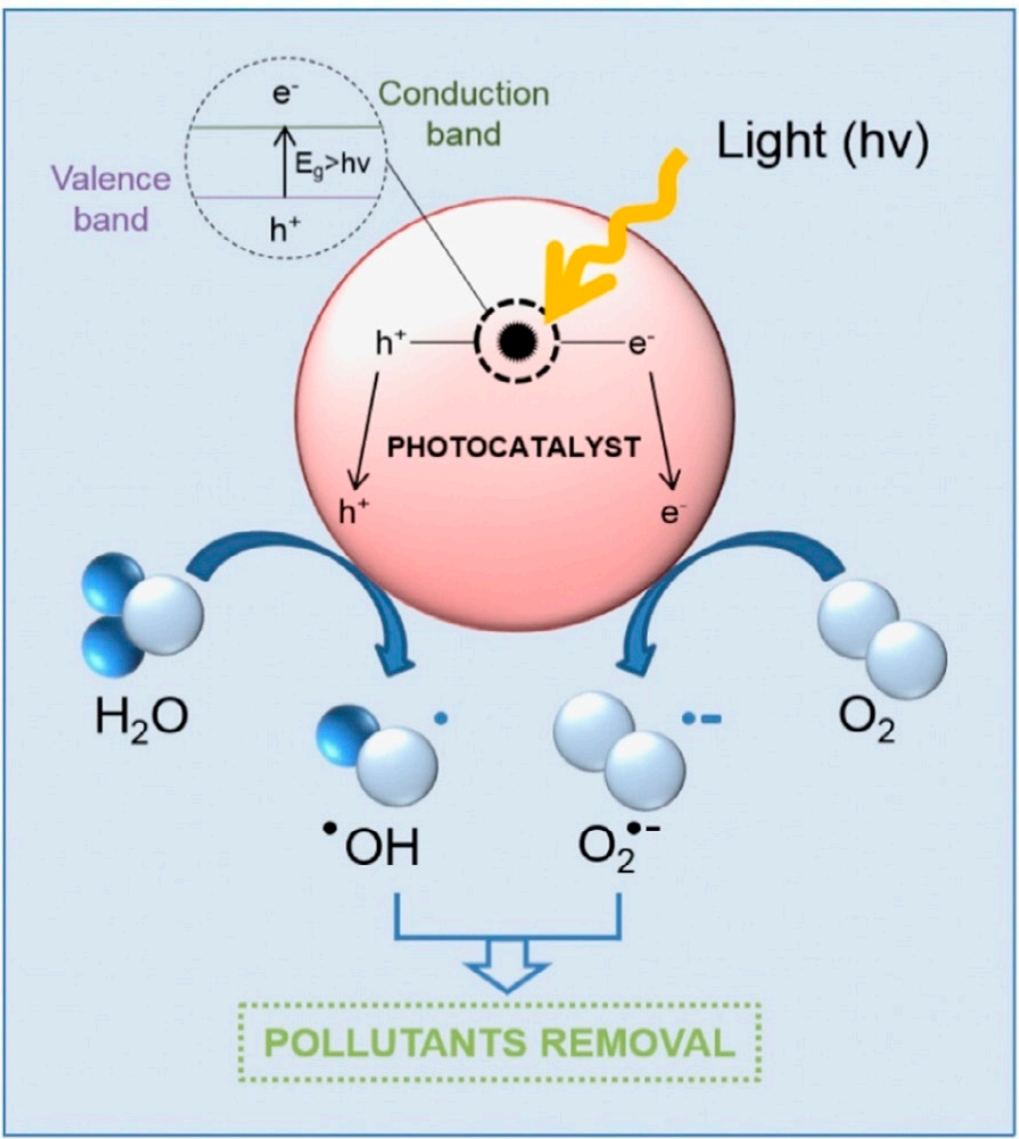

(A)

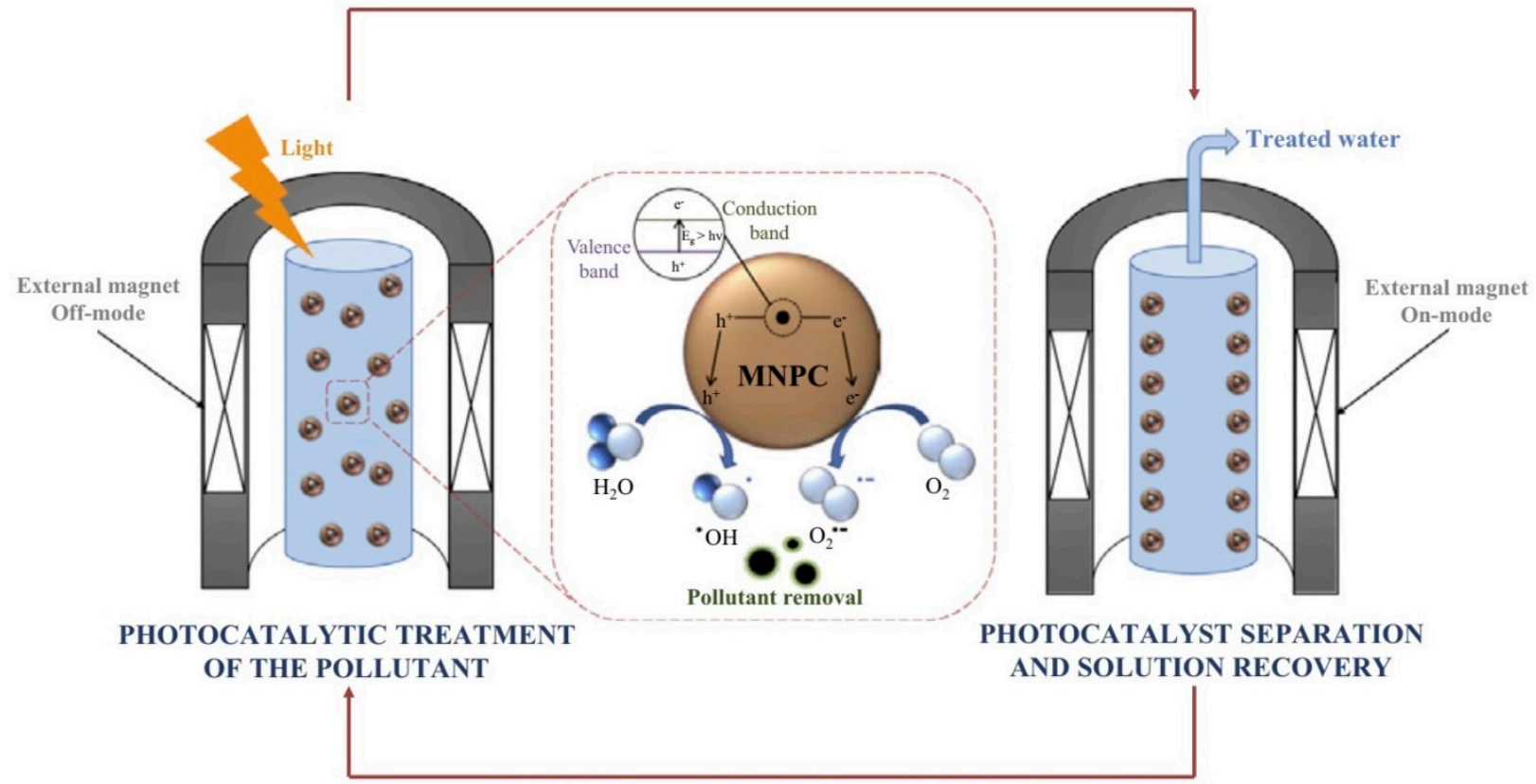

(B)

Figure 4. Graphical representation of (A) excitation of a nanophotocatalyst during the photocatalytic process; (B) photocatalytic treatment of polluted water and recovery of nanophotocatalyst (Reproduced with permission from [130]). 
Some typically used nanostructured semiconductor photocatalysts are $\mathrm{TiO}_{2}, \mathrm{Fe}_{2} \mathrm{O}_{3}$, $\mathrm{ZnO}$, zirconium dioxide $\left(\mathrm{ZrO}_{2}\right)$, zinc sulfide $(\mathrm{ZnS})$, tungsten trioxide $\left(\mathrm{WO}_{3}\right)$, and cadmium sulfide (CdS) [135]. Bai et al. synthesized $\mathrm{TiO}_{2}$ loaded ordered mesoporous silica (SBA-15) molecular sieve deposited with zirconium nanophotocatalyst and evaluated its photocatalytic efficiency to degrade reactive red X-3B. The synthesized system was easily affected by $\mathrm{pH}$ variation and under optimal conditions it displayed $96 \%$ of degradation rate for reactive brilliant red X-3B dye [136]. Mahmoudian and coworkers fabricated silver (Ag) doped- $\mathrm{TiO}_{2}$ nanophotocatalyst for efficient degradation of recombinant DNA (rDNA) present in wastewater coming from a Hepatitis B surface antigen production plant. Upon evaluation, it was found that $\mathrm{Ag}$-doped $\mathrm{TiO}_{2}$ nanophotocatalysts have a great capability to degrade rDNA. Furthermore, calcination temperature and concentration of silver (Ag) had a significant effect on rDNA degradation. The rDNA degradation efficiency of synthesized nanophotocatalysts was found to be $80.7 \%$ [137].

As the use of antibiotics have increased, their presence in wastewater has also significantly increased. Ciprofloxacin (CIP) is one of the most widely used antibiotics globally and hence its occurrence in wastewater is increasing day by day. In order to remove CIP from wastewater, Malakootian et al. synthesized a heterogeneous magnetic nanophotocatalyst using carboxy methyl cellulose to remove CIP. The fabricated catalyst was characterized by its photocatalytic potential to remove CIP, its chemical stability and its reusability. The investigators found superior chemical stability, reusability and excellent CIP removal potential for designed magnetic nanophotocatalysts [138]. Similarly, Karimi and coworkers envisaged the synthesis of nanophotocatalysts using $\mathrm{Fe}_{3} \mathrm{O}_{4}$ NPs along with zinc sulfide quantum dots (ZnS-QDs), and N, S- doped graphene quantum dots (N, S-G@QDs) and compared its photodegradation ability with an organic dye pollutant, Victoria blue R (VBR), in aqueous media. The maximum photodegradation ability was found to be $96.68 \%$ for $\mathrm{Fe}_{3} \mathrm{O}_{4}$-N, S-G@QDs at pH 9, whereas $\mathrm{Fe}_{3} \mathrm{O}_{4}$-ZnS@QDs showed $93.44 \%$ of degradation at $\mathrm{pH} 8$, after 120 min irradiation [139].

Occurrence of organic dyes such as $\mathrm{MO}, \mathrm{RhB}$ and acid orange (AO7) have significantly increased in wastewater and their removal is a matter of concern. Yosefi et al. synthesized a $\mathrm{p}$-n junction (formed by $\mathrm{p}$ type and $\mathrm{n}$ type semiconductor) flower-like nanophotocatalyst for removal of $\mathrm{AO} 7$ from wastewater. Bismuth oxyhalides (BiOX), namely, bismuth oxyiodide $(\mathrm{BiOI})$, were used as $\mathrm{p}$ type and $\mathrm{Zinc}$ ferrite $\left(\mathrm{ZnFe}_{2} \mathrm{O}_{4}\right)$ as n-type semiconductors. Fabricated $\mathrm{P} @ \mathrm{BiOI} / \mathrm{N} @ \mathrm{ZnFe}_{2} \mathrm{O}_{4}$ showed $96 \%$ of degradation efficiency for AO7 in $3 \mathrm{~h}$ as compared to $\mathrm{BiOI}$ and $\mathrm{ZnFe}_{2} \mathrm{O}_{4}$, alone [140]. Similarly, Margan et al. prepared ultrasound-assisted cadmium oxide-zinc oxide nanophotocatalyst $(\mathrm{CdO}-\mathrm{ZnO})$ for elimination of $\mathrm{AO}$. The photocatalytic degradation ability of this synthesized catalyst was found to be $69 \%$ within $140 \min [141]$.

\subsection{Disinfection and Pathological Control}

According to the World Health Organization (WHO), 80\% of diseases in developing countries are caused by consumption of water contaminated by pathogens including bacteria, viruses, prions, fungi, protozoa and rickettsia, that poses a serious threat to human health and take millions of lives each year around the world [142-145]. Disinfection is the process of reduction of the microbial count onto the surface or bulk of the material to an acceptable extent by physical or chemical means [146]. Traditional disinfection techniques adopted for wastewater treatment include free chlorine, hypochlorite, chlorine dioxide, chloramines, ozone, reverse osmosis and peracetic acid [147-149]. However, use of these techniques are limited because of their huge energy consumption, the need for expensive equipment and numerous DBPs, which raises other concerns [150,151]. Hence, there is an urgent need to develop efficient, sustainable, low-cost, inexpensive, less tedious and time saving disinfection methods [152].

Nanomaterials are endowed with elite functionality for inactivation of pathogens in water, such as large surface areas and specific reactivity, which cannot be achieved via conventional methods [153]. The inactivation mechanism of these nanomaterials include 
surface-based electrostatic interaction and photochemical reactions, which induces the generation of reactive oxygen species (ROS), the disruption of cell walls and targeted delivery of disinfecting agents [154-157] (Figure 5). Owing to great surface properties and the reactivity of these nanomaterials, inhibition of pathogens in water could be done easily [158]. Nanomaterials based on $\mathrm{Ag}, \mathrm{CuO}, \mathrm{ZnO}, \mathrm{TiO}_{2}$, polymeric NPs and CNTs have been investigated for the disinfection of wastewater [159-164].

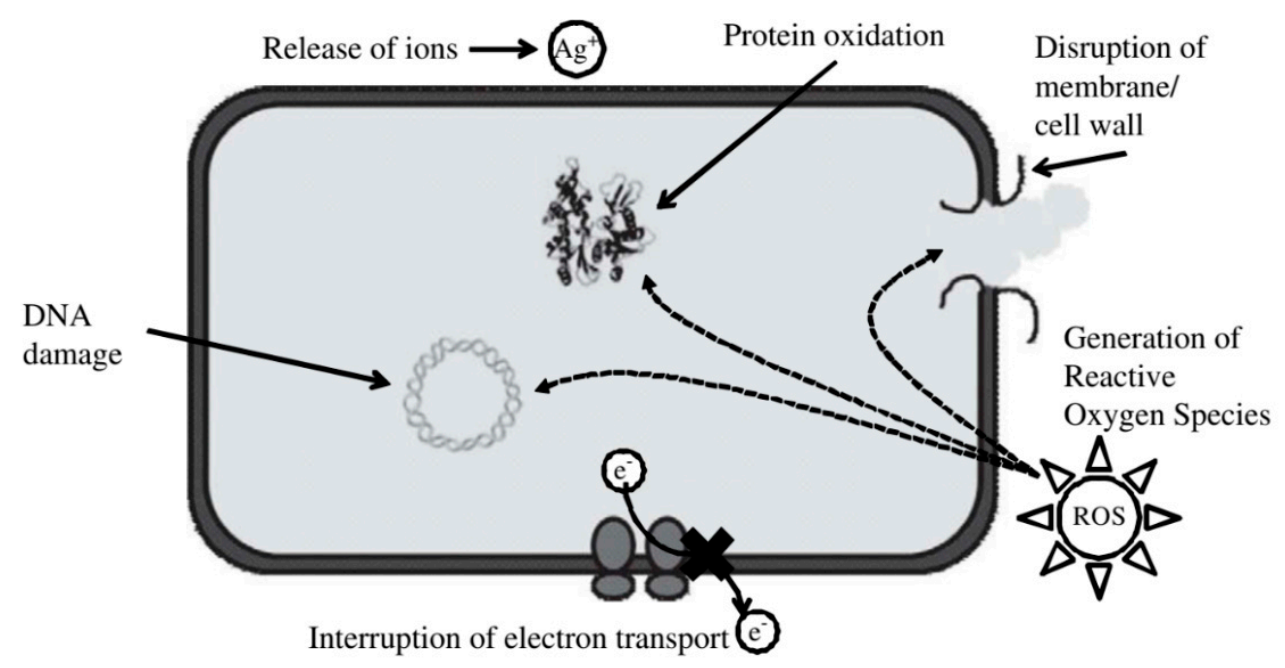

Figure 5. Schematic presentation of the different mechanisms of antimicrobial action of nanomaterials (Reproduced with permission from [161]).

$\mathrm{Ag}$ has been known for its antimicrobial activity for more than a thousand years, and is still one of the most widely used NPs in microbial (bacteria, viruses, and fungi etc.) disinfection agents $[165,166]$. Consequently, reusable core-shell Ag@ZnO NPs have been developed in order to disinfect pathogenic bacteria counting E. coli and Staphylococcus aureus. The results evidenced complete elimination of both bacterial strains within 60 and 90 min of solar photocatalysis at $35^{\circ} \mathrm{C}$, respectively. Ag@ZnO core shell NPs in aqueous phase and higher efficiency was observed at $55^{\circ} \mathrm{C}$ temperature. The best possible mechanism of action of $\mathrm{Ag} @ \mathrm{ZnO}$ was proposed to be the generation of ROS during the catalysis, which leads to the damage of the bacterial cell walls [167]. ZnO NPs are one of the most biocompatible and environmentally friendly NPs [168]. To inactivate E. Coli, $\mathrm{ZnO} N$ Ps were synthesized at varying $\mathrm{pHs}$ using surfactant-free reflux production techniques, which displayed potential antibacterial properties [169]. ZnO nanocrystal-doped macro mesoporous three-dimensional nanostructure silicon ( $\mathrm{Si}$ )-wafers exhibited potential antibacterial activity for the model organism E. coli. The antibacterial activity of $\mathrm{ZnO}$ potentially increased in conjunction with Si-wafers [170].

Among the metal NPs, copper $(\mathrm{Cu})$ NPs are some of the most effective and potent antimicrobial agents. One green synthesis approach for fabrication of antibacterial copper oxide $(\mathrm{CuO}) \mathrm{NPs}(\mathrm{CuO} \mathrm{NPs})$ was reported by Gul et al., where they fabricated NP CuONPs in the mixed matrices of PES and cellulose acetate by using casting techniques. Cu@pes-CACuO-1 (III) and Cu@PES-CACuO- 2 (IV) showed more than 75\% inhibition, demonstrating excellent use of $\mathrm{Cu}$ as an antibacterial NP [171]. Another approach for synthesis of CuNPs from biowaste eggshell membrane was stated by He et al., using biotemplated methods and its antibacterial property was tested on model microorganisms such as E. coli and $S$. aureus. The antibacterial effect was indicated by the zone of inhibition for E. coli and S. aureus, which was found to be 20.3 and $27.5 \mathrm{~mm}$, respectively. The synthesized CuO NPs showed a high recyclability [172]. 


\subsection{Sensing and Monitoring}

The environment has been contaminated by the presence of several living/non-living stuffs (e.g., disease causing microorganism, municipal/industrial waste, sewage discharge, animal defecation and heavy metals) [173]. Monitoring of water quality, on large as well as small scales, is a challenging task because of the extremely low concentrations of contaminants, complexity and variability of the wastewater matrices [174]. In order to address these issues, fast and efficient techniques need to be developed. In recent years, the scientific community have been more inclined towards the development of nanomaterialbased sensors to monitor water quality. Owing to their excellent properties, such as proficient recognition of trace contaminants, and fast analysis $[8,175,176]$, nanosensors can be defined as device/material sensitive towards changes in surrounding stimuli, such as heat, chemical and mechanical stress, changes in volume, concentration, gravitational and magnetic, as well as electrical forces, and are used to convey physical, chemical or biological information about the behavior and characteristics of NPs from the nanoscale level to the macroscopic level $[177,178]$. Nanosensors consist of three main parts, namely a recognizing component (nanometals, nanotubes, nanowires, NPs, etc.) connected to a transducer (voltammetric, amperometric, conductometric, spectrophotometric, etc.) and a display for real time monitoring $[179,180]$.

Biological contaminants such as antibiotic-resistant pathogens and their antibioticresistance genes (ARGs) are rising in wastewater continuously and this is daunting for public health. Methicillin-resistant S. aureus (MRSA) is a tarnished antibiotic-resistant pathogen whose mecA, an ARG of MRSA, is found to be responsible for antibiotic resistance. Riquelme and coworkers synthesized gold nanosensors functionalized with oligonucleotide for environmental monitoring of mecA ARG. The ARG spike detection test of synthesized nanosensors was performed in wastewater treatment plant effluent and it showed a high selectivity for ARG with the limit of detection of $70 \mathrm{ppm}$ [181].

These days, organophosphorus (OP) compounds are being used widely as pesticides. As a result, their concentration in agricultural runoff, wastewater from industries and rivers has increased a lot. Since they are neurotoxic, their presence in water, even in traces, is harmful. Therefore, to detect OP compounds (diazinon pesticide) in tap water, agricultural runoff and rivers, Talari et al. designed aptamer-based optical nanosensors, utilizing reduced GO quantum dots (rGQDs) and MWCNTs. The nanosensors showed selectivity for diazinon and detected it promptly with a high accuracy [182]. Triclosan (TCS) is an antifungal and antibacterial agent widely used in household cleaning and personal care products. Extensive use of TCS and its subsequent release into wastewater, sediments and other water sources causes chronic toxicity to aquatic organisms as well as posing a risk to human health. Atar et al. developed a chemical nanosensor based on molecular-imprinted surface plasmon resonance (SPR) to detect TCS in wastewater. The developed nanosensor was applied to wastewater samples and the result revealed the excellent performance of the sensor [183].

Caffeine is a pharmaceutical and personal care product (PPCP), released abundantly in the environment by means of pharmaceutical wastewater, colas, tea, coffee beans, drugs and energy drinks. Hu et al. developed a chemical nanosensor based on AgNPs doped in molecularly imprinted polymers (MIP) for caffeine detection in wastewater. The detection limit of AgNPs@MIP for caffeine was found to be $100 \mathrm{ng} \mathrm{L}^{-1}$, which is less than the reported caffeine content in many rivers [184].

$\mathrm{Cr}$ is commonly used in steel manufacturing, painting, leather tanning, welding and as a catalyst as well. The extensive use of $\mathrm{Cr}$ has resulted in a tremendous increase in $\mathrm{Cr}$ contamination, which has perceptible adverse effects on biological and ecological systems. For the most part, $\mathrm{Cr}$ is found in two states of oxidation: trivalent chromium $\mathrm{Cr}$ (III) and hexavalent chromium $\mathrm{Cr}$ (VI). Cr (III) is an essential trace element for human nutrition, whereas $\mathrm{Cr}(\mathrm{VI})$ has mutagenetic and carcinogenetic effects on living organisms. In order to detect $\mathrm{Cr}(\mathrm{VI})$ in environmental water samples, Zhang et al. synthesized a carbon dot-based 
nanosensor. The synthesized nanosensor was found to be sensitive to $\mathrm{Cr}$ (VI) with the detection limit of $2.3 \mathrm{nM}$ at $\mathrm{pH} 6$ [185].

\section{Barriers and Risks Associated with Nanotechnology}

Although nanotechnology demonstrates promising outcomes in wastewater treatment, there are significant barriers that stand between these promises and their delivery. The most common barriers include nanomaterial toxicity, cost effectiveness and social acceptability. The risks associated include transformation of nanomaterials, ecotoxicity associated with engineered nanomaterials and water pollution [186].

\subsection{Nanomaterial Toxicity}

There have been many previous cases of wastewater treatment methodologies which have resulted in unwanted after effects. Chlorination is one of the conventional wastewater treatment methods which had been anticipated to contribute in enhanced life expectancy across the world, but was later noticed to generate carcinogenic byproducts like N-nitrosodimethylamine and trihalomethanes [187]. This could also be related to the utilization of nanotechnology in wastewater treatment. The properties which are responsible for the usefulness of nanomaterials are the ones which also make them liable for the resulting toxicity. Toxicity depends on the molecular structure of components dictating the toxicity end point and size, which regulates cellular uptake. Due to its small size, NPs penetrate through epithelial and endothelial barriers into the lymph and blood to various organs and tissues, including the brain, heart, liver, kidneys, spleen, bone marrow and nervous system [188]. Size- and shape-dependent toxicity is reported for Ag NPs, CNTs and many other metal NPs. The size of NPs (from 1 to $100 \mathrm{~nm}$ ) are akin to the size of protein globules $(2-10 \mathrm{~nm})$, DNA helix $(2 \mathrm{~nm})$ and thicknesses of cell membranes $(10 \mathrm{~nm})$, allowing easy entry to cells and cell organelles [189].

Huo et al. reported that gold NPs of sizes less than $6 \mathrm{~nm}$ effectively enter the nucleus, while larger NPs of sizes 10-16 nm only penetrate through the cell membrane, and are thus found in the cytoplasm. $\mathrm{TiO}_{2} \mathrm{NPs}$ are reported to make conformational changes in tubulin and inhibit its polymerization, thus disturbing intracellular transport, cell division and cell migration. NPs can be of different shapes, including spheres, ellipsoids, cylinders, sheets, cubes and rods. Spherical NPs are more prone to endocytosis than nanotubes and nanofibers. SWCNTs have been found to more effectively block calcium channels compared to spherical NPs. Hydroxyapatite NPs of different shapes, such as plate-like, rod-like, needle-like and spherical shapes, were evaluated for toxicity and demonstrated that platelike and needle-like NPs resulted in the death of a larger proportion of nontumorigenic lung epithelial cells (BEAS-2B cells) as compared to spherical and rod-like NPs. Different mechanisms of cell damage by NPs are depicted diagrammatically in Figure 6.

An extensive toxicological database is available for bulk counterparts and shared constituents of nanomaterials benefit risk assessment. However, fullerenes and CNTs (allotropic nanomaterials) do not have bulk counterparts, which preclude such assessments and demonstrate the need for more vigilant toxicity studies. In a comprehensive prospective, a risk assessment should be considered at every stage in the life cycle of nanomaterials. 


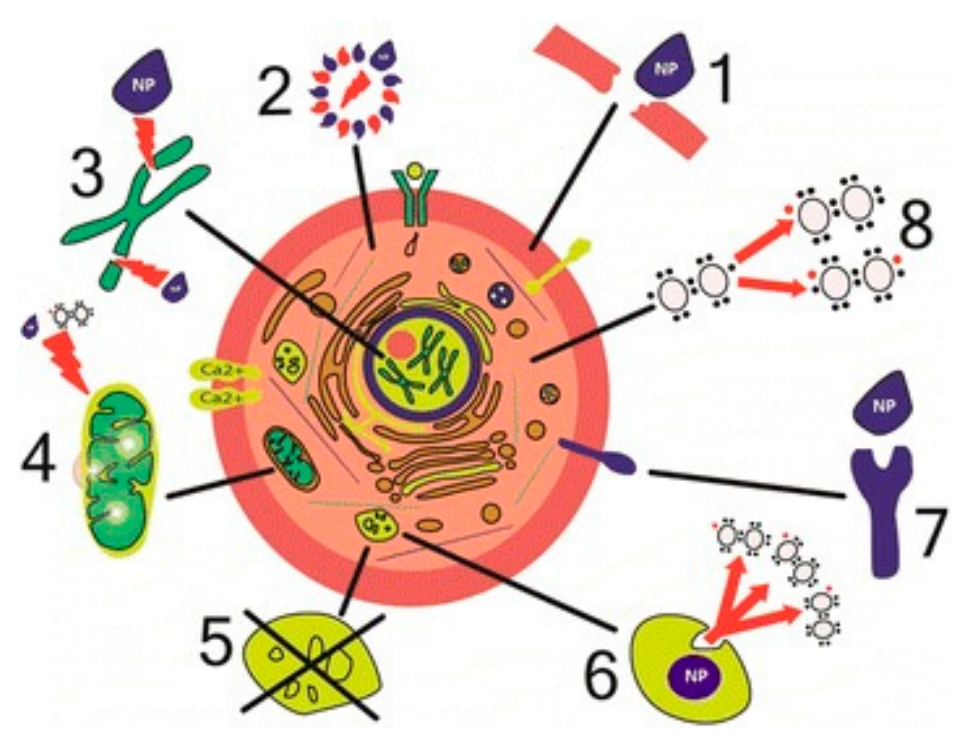

Figure 6. Mechanisms of cell damage by NPs. (1) Physical damage of membranes. (2) Structural changes in cytoskeleton components. (3) Disturbance of transcription and oxidative damage of DNA. (4) Damage of mitochondria. (5) Disturbance of lysosome functioning. (6) Generation of reactive oxygen species. (7) Disturbance of membrane protein functions. (8) Synthesis of inflammatory factors and mediators (Reproduced with permission from [189]).

\subsection{Cost Effectiveness}

The performance and affordability of the nanotechnology for wastewater treatment eventually affects their acceptance. Developed countries use advanced technologies for wastewater treatment to remove wide spectrum of pollutants, while in developing countries it often covers the most basic needs (e.g., disinfectant). In both cases, there is a need to treat progressively complex contaminant mixtures to get a higher water quality at a lower cost, which pushes the boundaries of recent wastewater treatment models. Therefore, this cost barrier is significant but not impossible to overcome. A substantial fraction of the nanomaterial production cost is related to separation and purification. The cost of nanomaterials of research grade having high purity and uniform properties are having considerably constant prices from the last two decades and they are unlikely to drop significantly without increased demand and production scale-up. Moreover, the reasonability of using nanomaterials for wastewater treatment can be enhanced by producing nanomaterials of lower purity. For example, ultrapure $\mathrm{C}_{60}$ replaced with fullerene soot to make amino-fullerene photocatalysts, which exhibited a minimal loss of effectiveness with approximately $90 \%$ cost reduction $[8,190]$. Additionally, cost-effectiveness of nanomaterials can be enhanced by their long-term reusability. The example includes photocatalysts that retain its activity through the regeneration of nanoadsorbents, and magnetically separable multifunctional nanomaterials, which permits multiple reuse cycles [191].

\subsection{Nanomaterial Transformation Risk in Water}

Mode of interaction amid biotic-nanomaterials and abiotic factors, dispersibility/solubility governs the fate of nanomaterials. Generally, NPs settle slowly compared to larger particles, but because of their large surface area, they adsorb more sediment particles and soil, and due to their high insolubility in water (CNTs and fullerenes), they can easily be removed using water columns. The engineered nanomaterials are sometimes used for special purposes, i.e., pristine-engineered nanomaterials, which are prone to get transformed to various other forms, i.e., product-modified, product-weathered and environmentally transferred engineered nanomaterials. The light can bring out photochemical transformation and oxidation reduction can sometimes be favored. These transformations alter the interactions 
between nanomaterials and the environment, which eventually governs the adsorption and desorption of contaminants in water [192].

\subsection{Ecotoxicity Associated with Nanomaterials}

Ecotoxicity refers to the likeliness of chemical, physical or biological stressors to disturb the ecosystem. The nanomaterials have a potential risk of leaching into the treated water during production, use and discarding of NP-containing products. Moreover, there are higher production rates per year for emerging metal NPs like $\mathrm{Ag}$ and $\mathrm{TiO}_{2}$ [193]. These emerging nanomaterials are considered a great worry to the aquatic environment, as proved in one study where the inhibitory effects of $\mathrm{Ag} \mathrm{NPs}_{\mathrm{s}}$ and $\mathrm{TiO}_{2}-\mathrm{NPs}$ was investigated on the growth of duckweed (aquatic plant) [194].

$\mathrm{NP}$ concentrations in some natural surface waters are estimated to be on the nano/micro $\mathrm{g} / \mathrm{L}$ scale. Theses concentrations increase with the enhanced production of NPs. Ag, titanium and zinc oxide NPs are used for their antibacterial properties to purify water in most developing countries, and replace chemical disinfectants [195]. Ceramic filters impregnated with Ag NPs are also used. Filtered water through nano Ag-coated filter papers showed detectable levels of Ag NPs, which were considerably below the limit set by the WHO's guidelines [196]. Very few literature reports mentioned the studies investigating leached NPs from treated water and their toxicity on experimental animals. Some studies reported vital organ damage and DNA damage in rats, which were ingesting $\mathrm{TiO}_{2}$ in NP-contaminated water. Similarly, engineered nanomaterials are reported to initiate some health concerns, including pulmonary inflammation, genotoxicity, carcinogenicity and circulatory effects [197].

\subsection{Water Pollution}

Several laboratories work on toxicities caused due to nanomaterial-polluted water. Cimbaluk et al. evaluated the toxic effects of MWCNTs in two species of fish, Astyanax altiparanae and Danio rerio, where they find the possibility of CNTs-DNA crosslinking, the generation of oxidative stress and acute and subchronic neurotoxicity in species, respectively [198]. Similarly, Khan et al. studied the effects of Ag NP-treated water on fresh water fish (Labeo rohita), where they observed an elevation in oxidative stress and genotoxicity [199]. The toxicity is also reported to be due to the dispersant used for dispersing nanomaterials as they are poorly solubilized in water. For example, tetrahydrofuran is a very good dispersant used for $\mathrm{CNTs}_{\mathrm{S}}$ and $\mathrm{C}_{60}$ fullerenes, which raises concerns about its toxicity [200].

The use of nanotechnology in wastewater treatment is subjected to systematic investigation of possible biological and ecotoxicity associated with their use. After ruling out any such possibility, the application of nanotechnology may result in promising outcomes in this arena, depending on the tactics being investigated by scientists to reduce the costs associated with nanomaterials. However, the initial results support the promising efficacy of nanotechnology in wastewater treatment and further optimization is supposed to increase their safety threshold.

\section{Conclusions}

Across the globe, the demand for clean and safe water is increasing with the rapid increase in population, expanding industrialization, urbanization and extensive agriculture practices. Various techniques are currently being used for the decontamination and purification of water. However, these methods often involve chemicals, and are energetically and operationally intensive, and hence require engineering expertise and infrastructure. Currently, there is a need for the development of novel wastewater treatment methodologies for the withdrawal of contaminants from wastewater. Nanotechnology could be one of the potential options in this aspect for nanomaterial-based wastewater treatment. Nanostructure materials are enriched with unique properties, such as high surface-to-volume ratios, high sensitivity and reactivity, high adsorption capacity and ease of functional- 
ization. Owing to these properties, they have the potential to overcome the problems associated with traditional methods. However, another aspect of nanotechnology is the risk associated with it. Many issues have been reported by various researchers allied with a number of applications and properties of nanomaterials. Since they possess a very small size, they can be transmitted to human or other aquatic animal's bodies and may cause toxicity. The further extent of toxicity greatly depends on surrounding conditions such as $\mathrm{pH}$, concentration and contact time. Although scientists have explored nanotechnology a lot, a greater endeavor is obligatory in order to explore each and every corner of this new technology. The use of nanotechnology looks very promising for wastewater management and could have a great future in this regard, but a sincere and dedicated effort from the scientific community and government bodies is needed.

Author Contributions: K.J. and S.J.S.F. conceptualized, designed and prepared first and final draft of the manuscript. A.S.P. and V.P.P. reviewed the development of nanotechnology in wastewater treatment and limitations associated with the use of nanomaterials. All authors have read and agreed to the published version of the manuscript.

Funding: This research received no external funding.

Institutional Review Board Statement: Not applicable.

Informed Consent Statement: Not applicable.

Data Availability Statement: Not applicable.

Acknowledgments: We acknowledge the Department of Pharmaceuticals (DoP), Ministry of Chemicals and Fertilizers, Government of India, for their support. The NIPER Raebareli communication number for this publication is NIPER-R/Communication/182.

Conflicts of Interest: The authors declare no conflict of interest.

\section{References}

1. Definition of Freshwater Resources. Available online: https://web.archive.org/web/20160411064155/http://webworld.unesco. org/water/ihp/publications/waterway/webpc/definition.html (accessed on 25 January 2021).

2. Kurniawan, T.A.; Sillanpää, M.E.; Sillanpää, M. Nanoadsorbents for Remediation of Aquatic Environment: Local and Practical Solutions for Global Water Pollution Problems. Crit. Rev. Environ. Sci. Technol. 2012, 42, 1233-1295. [CrossRef]

3. Olvera, R.C.; Silva, S.L.; Robles-Belmont, E.; Lau, E.Z. Review of nanotechnology value chain for water treatment applications in Mexico. Resour. Technol. 2017, 3, 1-11. [CrossRef]

4. Singh, I.; Mishra, P.K. Nano-membrane filtration a novel application of nanotechnology for waste water treatment. Mater. Today Proc. 2020, 29, 327-332. [CrossRef]

5. Kamali, M.; Persson, K.M.; Costa, M.E.; Capela, I. Sustainability criteria for assessing nanotechnology applicability in industrial wastewater treatment: Current status and future outlook. Environ. Int. 2019, 125, 261-276. [CrossRef] [PubMed]

6. Kumar, S.; Ahlawat, W.; Bhanjana, G.; Heydarifard, S.; Nazhad, M.M.; Dilbaghi, N. Nanotechnology-Based Water Treatment Strategies. J. Nanosci. Nanotechnol. 2014, 14, 1838-1858. [CrossRef]

7. Yamamura, H.; Hashino, M.; Kubota, N. Membrane Filtration: Principle and Applications in Water Treatment. SEN-I GAKKAISHI 2011, 67, 3. [CrossRef]

8. Qu, X.; Brame, J.; Li, Q.; Alvarez, P.J.J. Nanotechnology for a Safe and Sustainable Water Supply: Enabling Integrated Water Treatment and Reuse. Acc. Chem. Res. 2012, 46, 834-843. [CrossRef]

9. Rajasulochana, P.; Preethy, V. Comparison on efficiency of various techniques in treatment of waste and sewage water-A comprehensive review. Resour. Technol. 2016, 2, 175-184. [CrossRef]

10. Zinicovscaia, I. Conventional Methods of Wastewater Treatment. In Cyanobacteria for Bioremediation of Wastewaters; Springer: Cham, Switzerland, 2016; pp. 17-25. [CrossRef]

11. Theron, J.; Walker, J.A.; Cloete, T.E. Nanotechnology and Water Treatment: Applications and Emerging Opportunities. Crit. Rev. Microbiol. 2008, 34, 43-69. [CrossRef]

12. Humplik, T.; Lee, J.; O’Hern, S.C.; Fellman, B.A.; Baig, M.A.; Hassan, S.F.; Atieh, M.A.; Rahman, F.; Laoui, T.; Karnik, R.; et al. Nanostructured materials for water desalination. Nanotechnology 2011, 22, 292001. [CrossRef]

13. Khan, I.; Saeed, K.; Khan, I. Nanoparticles: Properties, applications and toxicities. Arab. J. Chem. 2019, 12, 908-931. [CrossRef]

14. Jain, K. Dendrimers: Smart nanoengineered polymers for bioinspired applications in drug delivery. In Biopolymer-Based Composites: Drug Delivery and Biomedical Applications; Woodhead Publishing: Cambridge, UK, 2017; pp. 169-220.

15. Jain, K. Nanohybrids of Dendrimers and Carbon Nanotubes: A Benefaction or Forfeit in Drug Delivery? Nanosci. Nanotechnol. Asia 2018, 9, 21-29. [CrossRef] 
16. Ritter, K.S.L. Sources, Pathways, and Relative Risks of Contaminants in Surface Water and Groundwater: A Perspective Prepared for the Walkerton Inquiry. J. Toxicol. Environ. Health Part A 2002, 65, 1-142. [CrossRef]

17. Rajasekhar, B.; Nambi, I.M.; Govindarajan, S.K. Human health risk assessment of ground water contaminated with petroleum PAHs using Monte Carlo simulations: A case study of an Indian metropolitan city. J. Environ. Manag. 2018, 205, $183-191$. [CrossRef]

18. Rodriguez-Proteau, R.; Grant, R.L. Toxicity Evaluation and Human Health Risk Assessment of Surface and Ground Water Contaminated by Recycled Hazardous Waste Materials. In Water Pollution: The Handbook of Environmental Chemistry; Kassim, T.A., Ed.; Springer: Berlin/Heidelberg, Germany, 2005; Volume 2, pp. 133-189. [CrossRef]

19. Ahmad, H.R.; Aziz, T.; Zia-Ur-Rehman, M.; Sabir, M.; Khalid, H.; Hakeem, K.R.; Akhtar, J. Sources and Composition of Waste Water: Threats to Plants and Soil Health. In Soil Science: Agricultural and Environmental Prospectives; Hakeem, K., Akhtar, J., Sabir, M., Eds.; Springer: Cham, Switzerland, 2016; pp. 349-370. [CrossRef]

20. Jassby, D.; Cath, T.Y.; Buisson, H. The role of nanotechnology in industrial water treatment. Nat. Nanotechnol. 2018, 13, 670-672. [CrossRef]

21. Deshpande, B.; Agrawal, P.; Yenkie, M.; Dhoble, S. Prospective of nanotechnology in degradation of waste water: A new challenges. Nano-Struct. Nano-Objects 2020, 22, 100442. [CrossRef]

22. Warwick, C.; Guerreiro, A.; Soares, A. Sensing and analysis of soluble phosphates in environmental samples: A review. Biosens. Bioelectron. 2013, 41, 1-11. [CrossRef]

23. Introduction to Wastewater Treatment-Google Books. Available online: https:/ /books.google.co.in/books?hl=en\&lr=\&id= yjT4w5cjrM0C\&oi=fnd\&pg=PA7\&dq=Templeton, + M.+R., +\%26+Butler, +D.+(2011).+Introduction+to+wastewater+treatment. +London,+UK:+Bookboon\&ots=dwyi24NVe1\&sig=fhPmx-HoQO6j9c7YwaypWnyYyNc\#v=onepage\&q\&f=false $($ accessed on 26 January 2021).

24. Ahmadi, F.; Zinatizadeh, A.A.; Asadi, A.; McKay, T.; Azizi, S. Simultaneous carbon and nutrients removal and PHA pro-duction in a novel single air lift bioreactor treating an industrial wastewater. Environ. Technol. Innov. 2020, 18, 100776. [CrossRef]

25. Aboelfetoh, E.F.; Elabedien, M.E.Z.; Ebeid, E.-Z.M. Effective treatment of industrial wastewater applying SBA-15 mesoporous silica modified with graphene oxide and hematite nanoparticles. J. Environ. Chem. Eng. 2021, 9, 104817. [CrossRef]

26. Sher, F.; Hanif, K.; Iqbal, S.Z.; Imran, M. Implications of advanced wastewater treatment: Electrocoagulation and electroflocculation of effluent discharged from a wastewater treatment plant. J. Water Process Eng. 2020, 33, 101101. [CrossRef]

27. Runguphan, T.; Kitpichai, J. Coaction of bio-sorption and bio-filtration for the remediation of domestic and agricultural wastewater contaminated with heavy metal. IOP Conf. Ser. Mater. Sci. Eng. 2020, 965, 012010. [CrossRef]

28. Kalfa, A.; Shapira, B.; Shopin, A.; Cohen, I.; Avraham, E.; Aurbach, D. Capacitive deionization for wastewater treatment: Op-portunities and challenges. Chemosphere 2020, 241, 125003. [CrossRef]

29. Verlicchi, P.; Al Aukidy, M.; Zambello, E. Occurrence of pharmaceutical compounds in urban wastewater: Removal, mass load and environmental risk after a secondary treatment-A review. Sci. Total Environ. 2012, 429, 123-155. [CrossRef]

30. Bora, T.; Dutta, J. Applications of nanotechnology in wastewater treatment-A review. J. Nanosci. Nanotechnol. 2014, 14, 613-626. [CrossRef]

31. Yamashita, T.; Yamamoto-Ikemoto, R. Nitrogen and phosphorus removal from wastewater treatment plant effluent via bacterial sulfate reduction in an anoxic bioreactor packed with wood and iron. Int. J. Environ. Res. Public Health 2014, 11, 9835-9853. [CrossRef]

32. Baruah, A.; Chaudhary, V.; Malik, R.; Tomer, V.K. Nanotechnology Based Solutions for Wastewater Treatment. In Nanotechnology in Water and Wastewater Treatment: Theory and Applications; Elsevier: Amsterdam, The Netherlands, 2019; pp. 337-368. [CrossRef]

33. Gusain, R.; Kumar, N.; Ray, S.S. Recent Advances in Carbon Nanomaterial-Based Adsorbents for Water Purification. Coord. Chem. Rev. 2020, 405, 213111. [CrossRef]

34. Crawford, C.B.; Quinn, B. The interactions of microplastics and chemical pollutants. In Microplastic Pollutants; Elsevier: Amsterdam, The Netherlands, 2017; pp. 131-157. [CrossRef]

35. Refaat Alawady, A.; Ali Alshahrani, A.; Ali Aouak, T.; Mohamed Alandis, N. Polysulfone membranes with CNTs/Chitosan biopolymer nanocomposite as selective layer for remarkable heavy metal ions rejection capacity. Chem. Eng. J. 2020, 15, 124267. [CrossRef]

36. Derco, J.; Vrana, B. Introductory Chapter: Biosorption. In Biosorption; IntechOpen: London, UK, 2018.

37. Seung, J.K.; Jae, H.C.; Tae, Y.K.; Sung, Y.C. Biosorption of heavy metals and cyanide complexes on biomass. In New Developments and Application in Chemical Reaction Engineering; Studies in Surface Science and Catalysis; Elsevier: Amsterdam, The Netherlands, 2006; pp. 141-144.

38. Yoon, J.; Cao, X.; Zhou, Q.; Ma, L.Q. Accumulation of $\mathrm{Pb}, \mathrm{Cu}$, and $\mathrm{Zn}$ in native plants growing on a contaminated Florida site. Sci. Total Environ. 2006, 368, 456-464. [CrossRef]

39. Fard, R.F.; Azimi, A.; Bidhendi, G.N. Batch kinetics and isotherms for biosorption of cadmium onto biosolids. Desalin. Water Treat. 2011, 28, 69-74. [CrossRef]

40. Yang, X.; Zhao, Z.; Yu, Y.; Shimizu, K.; Zhang, Z.; Lei, Z.; Lee, D.J. Enhanced biosorption of Cr (VI) from synthetic wastewater using algal-bacterial aerobic granular sludge: Batch experiments, kinetics and mechanisms. Sep. Purif. Technol. 2020, $251,117323$. [CrossRef] 
41. Ding, H.; Luo, X.; Zhang, X.; Yang, H. Alginate-immobilized Aspergillus niger: Characterization and biosorption removal of thorium ions from radioactive wastewater. Colloids Surf. A Physicochem. Eng. Asp. 2019, 562, 186-195. [CrossRef]

42. Nasir, S.; Hussein, M.Z.; Zainal, Z.; Yusof, N.A. Carbon-Based Nanomaterials/Allotropes: A Glimpse of Their Synthesis, Properties and Some Applications. Materials 2018, 11, 295. [CrossRef] [PubMed]

43. Sayed, E.T.; Alawadhi, H.; Elsaid, K.; Olabi, A.G.; Almakrani, M.A.; Bin Tamim, S.T.; Alafranji, G.H.M.; Abdelkareem, M.A. A Carbon-Cloth Anode Electroplated with Iron Nanostructure for Microbial Fuel Cell Operated with Real Wastewater. Sustainability 2020, 12, 6538. [CrossRef]

44. Ray, S.S.; Gusain, R.; Kumar, N. Carbon Nanomaterial-Based Adsorbents for Water Purification: Fundamentals and Applications; Elsevier: Amsterdam, The Netherlands, 2020.

45. Meng, H.; Xue, M.; Xia, T.; Zhao, Y.L.; Tamanoi, F.; Stoddart, J.F.; Zink, J.; Nel, A.E. Autonomous in vitro anticancer drug release from meso-porous silica nanoparticles by $\mathrm{pH}$-sensitive nanovalves. J. Am. Chem. Soc. 2010, 132, 12690-12697. [CrossRef]

46. Li, Y.; Zhou, B.; Zheng, G.; Liu, X.; Li, T.; Yan, C.; Cheng, C.; Dai, K.; Liu, C.; Shen, C.; et al. Continuously prepared highly conductive and stretchable SWNT/MWNT synergistically composited electrospun thermoplastic polyurethane yarns for wearable sensing. J. Mater. Chem. C 2017, 6, 2258-2269. [CrossRef]

47. Zhou, B.; Li, Y.; Zheng, G.; Dai, K.; Liu, C.; Ma, Y.; Zhang, J.; Wang, N.; Shen, C.; Guo, Z. Continuously fabricated transparent conductive polycarbonate/carbon nanotube nanocomposite films for switchable thermochromic applications. J. Mater. Chem. C 2018, 6, 8360-8371. [CrossRef]

48. Farghali, A.A.; Bahgat, M.; ElRouby, W.M.A.; Khedr, M.H. Decoration of multi-walled carbon nanotubes (MWCNTs) with dif-ferent ferrite nanoparticles and its use as an adsorbent. J. Nanostruct. Chem. 2013, 3, 1-12. [CrossRef]

49. Verma, B.; Balomajumder, C. Surface modification of one-dimensional Carbon Nanotubes: A review for the management of heavy metals in wastewater. Environ. Technol. Innov. 2020, 17. [CrossRef]

50. Moradi, O.; Fakhri, A.; Adami, S. Isotherm, thermodynamic, kinetics, and adsorption mechanism studies of Ethidium bromide by single-walled carbon nanotube and carboxylate group functionalized single-walled carbon nanotube. J. Coll. Interface Sci. 2013, 395, 224-229. [CrossRef]

51. Yadav, D.K.; Srivastava, S. Carbon nanotubes as adsorbent to remove heavy metal ion $(\mathrm{Mn}+7)$ in wastewater treatment. Mater. Today Proc. 2017, 4, 4089-4094. [CrossRef]

52. Kariim, I.; Abdulkareem, A.S.; Abubakre, O.K. Development and characterization of MWCNTs from activated carbon as adsorbent for metronidazole and levofloxacin sorption from pharmaceutical wastewater: Kinetics, isotherms and thermody-namic studies. Sci. Afr. 2020, 7, e00242.

53. Zhao, W.; Tian, Y.; Chu, X.; Cui, L.; Zhang, H.; Li, M.; Zhao, P. Preparation and characteristics of a magnetic carbon nanotube ad-sorbent: Its efficient adsorption and recoverable performances. Sep. Purif. Technol. 2021, 257, 117917. [CrossRef]

54. Yang, G.; Li, Y.; Yang, S.; Liao, J.; Cai, X.; Gao, Q.; Fang, Y.; Peng, F.; Zhang, S. Surface oxidized nano-cobalt wrapped by nitrogen-doped carbon nanotubes for efficient purification of organic wastewater. Sep. Purif. Technol. 2021, 259, 118098. [CrossRef]

55. Bankole, M.; Abdulkareem, A.; Tijani, J.; Ochigbo, S.; Afolabi, A.; Roos, W. Chemical oxygen demand removal from electroplating wastewater by purified and polymer functionalized carbon nanotubes adsorbents. Water Resour. Ind. 2017, 18, 33-50. [CrossRef]

56. Pirzada, M.; Altintas, Z. Nanomaterials for Healthcare Biosensing Applications. Sensors 2019, 19, 5311. [CrossRef]

57. Ali, I.; Basheer, A.A.; Mbianda, X.; Burakov, A.; Galunin, E.; Burakova, I.; Mkrtchyan, E.; Tkachev, A.; Grachev, V. Graphene based adsorbents for remediation of noxious pollutants from wastewater. Environ. Int. 2019, 127, 160-180. [CrossRef]

58. Ray, S.C. Application and Uses of Graphene Oxide and Reduced Graphene Oxide. In Applications of Graphene and Graphene-Oxide Based Nanomaterials; William Andrew Publishing: Norwich, NY, USA, 2015; pp. 39-55. [CrossRef]

59. Jayakaran, P.; Nirmala, G.S.; Govindarajan, L. Qualitative and Quantitative Analysis of Graphene-Based Adsorbents in Wastewater Treatment. Int. J. Chem. Eng. 2019, 2019, 1-17. [CrossRef]

60. Kyzas, G.Z.; Deliyanni, E.A.; Matis, K.A. Graphene oxide and its application as an adsorbent for wastewater treatment. J. Chem. Technol. Biotechnol. 2013, 89, 196-205. [CrossRef]

61. Chen, H.; Liu, T.; Meng, Y.; Cheng, Y.; Lu, J.; Wang, H. Novel graphene oxide/aminated lignin aerogels for enhanced adsorption of malachite green in wastewater. Coll. Surf. A Physicochem. Eng. Asp. 2020, 603, 125281. [CrossRef]

62. Bu, J.; Yuan, L.; Zhang, N.; Liu, D.; Meng, Y.; Peng, X. High-efficiency adsorption of methylene blue dye from wastewater by a thiosemicarbazide functionalized graphene oxide composite. Diam. Relat. Mater. 2020, 101, 107604. [CrossRef]

63. Lim Teik Zheng, A.; Phromsatit, T.; Boonyuen, S.; Andou, Y. Synthesis of silver nanoparticles/porphyrin/reduced graphene oxide hydrogel as dye adsorbent for wastewater treatment. FlatChem 2020, 23, 100174. [CrossRef]

64. Sirajudheen, P.; Karthikeyan, P.; Ramkumar, K.; Meenakshi, S. Effective removal of organic pollutants by adsorption onto chitosan supported graphene oxide-hydroxyapatite composite: A novel reusable adsorbent. J. Mol. Liq. 2020, 318, 114200. [CrossRef]

65. Awad, A.M.; Jalab, R.; Benamor, A.; Nasser, M.S.; Ba-Abbad, M.M.; El-Naas, M.; Mohammad, A.W. Adsorption of organic pollutants by na-nomaterial-based adsorbents: An overview. J. Mol. Liq. 2020, 301, 112335. [CrossRef]

66. Lu, H.; Wang, J.; Stoller, M.; Wang, T.; Bao, Y.; Hao, H. An Overview of Nanomaterials for Water and Wastewater Treatment. Adv. Mater. Sci. Eng. 2016, 2016, 1-10. [CrossRef]

67. Feng, L.; Cao, M.; Ma, X.; Zhu, Y.; Hu, C. Superparamagnetic high-surface-area $\mathrm{Fe}_{3} \mathrm{O}_{4}$ nanoparticles as adsorbents for arsenic removal. J. Hazard. Mater. 2012, 439-446. [CrossRef] 
68. Luo, T.; Cui, J.; Hu, S.; Huang, Y.; Jing, C. Arsenic Removal and Recovery from Copper Smelting Wastewater Using TiO 2 . Environ. Sci. Technol. 2010, 44, 9094-9098. [CrossRef]

69. Gupta, K.; Bhattacharya, S.; Chattopadhyay, D.; Mukhopadhyay, A.; Biswas, H.; Dutta, J.; Ray, N.R.; Ghosh, U.C. Ceria associated manganese oxide nanoparticles: Synthesis, characterization and arsenic(V) sorption behavior. Chem. Eng. J. 2011, 172, 219-229. [CrossRef]

70. Gao, C.; Zhang, W.; Li, H.; Lang, L.; Xu, Z. Controllable Fabrication of Mesoporous MgO with Various Morphologies and Their Absorption Performance for Toxic Pollutants in Water. Cryst. Growth Des. 2008, 8, 3785-3790. [CrossRef]

71. Singh, S.; Barick, K.C.; Bahadur, D. $\mathrm{Fe}_{3} \mathrm{O}_{4}$ embedded $\mathrm{ZnO}$ nanocomposites for the removal of toxic metal ions, organic dyes and bacterial pathogens. J. Mater. Chem. A 2013, 1, 3325-3333. [CrossRef]

72. Tadjarodi, A.; Imani, M.; Kerdari, H. Adsorption kinetics, thermodynamic studies, and high performance of CdO cauli-flower-like nanostructure on the removal of Congo red from aqueous solution. J. Nanostruct. Chem. 2013, 3, 1-8. [CrossRef]

73. Sadegh, H.; Ali, G.A.M.; Gupta, V.K.; Makhlouf, A.S.H.; Shahryari-Ghoshekandi, R.; Nadagouda, M.N.; Sillanpää, M.; Megiel, E. The role of nanomaterials as effective adsorbents and their applications in wastewater treatment. J. Nanostruct. Chem. 2017, 7, 1-14. [CrossRef]

74. El-Sayed, M.E. Nanoadsorbents for water and wastewater remediation. Sci. Total Environ. 2020, 739, 139903. [CrossRef]

75. Qu, X.; Alvarez, P.J.; Li, Q. Applications of nanotechnology in water and wastewater treatment. Water Res. 2013, 47, 3931-3946. [CrossRef]

76. He, L.; Wang, L.; Zhu, H.; Wang, Z.; Zhang, L.; Yang, L.; Dai, Y.; Mo, H.; Zhang, J.; Shen, J. A reusable $\mathrm{Fe}_{3} \mathrm{O}_{4} / \mathrm{GO}-\mathrm{COOH}$ nanoadsorbent for $\mathrm{Ca}^{2+}$ and $\mathrm{Cu}^{2+}$ removal from oilfield wastewater. Chem. Eng. Res. Des. 2021, 166, 248-258. [CrossRef]

77. Peralta, M.E.; Mártire, D.O.; Moreno, M.S.; Parolo, M.E.; Carlos, L. Versatile nanoadsorbents based on magnetic mesostructured silica nanoparticles with tailored surface properties for organic pollutants removal. J. Environ. Chem. Eng. 2021, 9, 104841. [CrossRef]

78. Sadak, O.; Hackney, R.; Sundramoorthy, A.K.; Yilmaz, G.; Gunasekaran, S. Azo dye-functionalized magnetic $\mathrm{Fe}_{3} \mathrm{O}_{4} / \mathrm{polyacrylic}$ acid nanoadsorbent for removal of lead (II) ions. Environ. Nanotechnol. Monit. Manag. 2020, 14, 100380. [CrossRef]

79. Arshadi, M.; Soleymanzadeh, M.; Salvacion, J.; SalimiVahid, F. Nanoscale Zero-Valent Iron (NZVI) supported on sineguelas waste for $\mathrm{Pb}(\mathrm{II})$ removal from aqueous solution: Kinetics, thermodynamic and mechanism. J. Coll. Interface Sci. 2014, 426, $241-251$. [CrossRef]

80. Jethave, G.; Fegade, U.; Attarde, S.; Ingle, S. Facile synthesis of Lead Doped Zinc-Aluminum Oxide Nanoparticles (LD-ZAO-NPs) for efficient adsorption of anionic dye: Kinetic, isotherm and thermodynamic behaviors. J. Ind. Eng. Chem. 2017, 53, 294-306. [CrossRef]

81. Pandey, N.; Shukla, S.K.; Singh, N.B. Water purification by polymer nanocomposites: An overview. Nanocomposites 2017, 3, 47-66. [CrossRef]

82. Berber, M.R. Current Advances of Polymer Composites for Water Treatment and Desalination. J. Chem. 2020, 2020 , 1-19. [CrossRef]

83. Reddy, D.H.K.; Lee, S.-M. Application of magnetic chitosan composites for the removal of toxic metal and dyes from aqueous solutions. Adv. Coll. Interface Sci. 2013, 68-93. [CrossRef] [PubMed]

84. Alaba, P.A.; Oladoja, N.A.; Sani, Y.M.; Ayodele, O.B.; Mohammed, I.Y.; Olupinla, S.F.; Daud, W.M.W. Insight into wastewater decontamination using polymeric adsorbents. J. Environ. Chem. Eng. 2018, 6, 1651-1672. [CrossRef]

85. Abdi, J.; Abedini, H. MOF-based polymeric nanocomposite beads as an efficient adsorbent for wastewater treatment in batch and continuous systems: Modelling and experiment. Chem. Eng. J. 2020, 400, 125862. [CrossRef]

86. Chen, B.; Chen, S.; Zhao, H.; Liu, Y.; Long, F.; Pan, X. A versatile $\beta$-cyclodextrin and polyethyleneimine bi-functionalized magnetic nanoadsorbent for simultaneous capture of methyl orange and $\mathrm{Pb}$ (II) from complex wastewater. Chemosphere 2019, 216, 605-616. [CrossRef] [PubMed]

87. Moharrami, P.; Motamedi, E. Application of cellulose nanocrystals prepared from agricultural wastes for synthesis of starch-based hydrogel nanocomposites: Efficient and selective nanoadsorbent for removal of cationic dyes from water. Bioresour. Technol. 2020, 313, 123661. [CrossRef] [PubMed]

88. Nithya Priya, V.; Rajkumar, M.; Mobika, J.; Linto Sibi, S.P. Alginate coated layered double hydroxide/reduced graphene oxide nanocomposites for removal of toxic As (V) from wastewater. Phys. E Low-Dimens. Syst. Nanostruct. 2021, 127, 114527. [CrossRef]

89. He, L.; Yang, L.; Zhang, L.; Wang, Z.; Cheng, H.; Wang, X.; Lv, C.; Zhang, J.; Mo, H.; Shen, J. Removal of Ca ${ }^{2+}$ and Mg ${ }^{2+}$ from oilfield wastewater using re-usable PEG/ $\mathrm{Fe}_{3} \mathrm{O}_{4} / \mathrm{GO}-\mathrm{NH} 2$ nanoadsorbents and its efficiency for oil recovery. J. Environ. Chem. Eng. 2020, 9, 104653. [CrossRef]

90. Strathmann, H.; Giorno, L.; Piacentini, E.; Drioli, E. 1.4 Basic Aspects in Polymeric Membrane Preparation. In Comprehensive Membrane Science and Engineering; Elsevier: Oxford, UK, 2017; pp. 65-84. [CrossRef]

91. Drisko, J.A. Chelation Therapy. In Integrative Medicine, 4th ed.; Rakel, D., Ed.; Elsevier: Amsterdam, The Netherlands, 2018; pp. 1004-1015.e3. [CrossRef]

92. Esmaeili, A.; Saremnia, B. Synthesis and characterization of NaA zeolite nanoparticles from Hordeum vulgare L. husk for the separation of total petroleum hydrocarbon by an adsorption process. J. Taiwan Inst. Chem. Eng. 2016, 61, 276-286. [CrossRef]

93. Ali, M.E.; Hoque, M.E.; Hossain, S.K.S.; Biswas, M.C. Nanoadsorbents for wastewater treatment: Next generation biotechnological solution. Int. J. Environ. Sci. Technol. 2020, 17, 4095-4132. [CrossRef] 
94. Noroozi, R.; Al-Musawi, T.J.; Kazemian, H.; Kalhori, E.M.; Zarrabi, M. Removal of cyanide using surface-modified Linde Type-A zeolite nanoparticles as an efficient and eco-friendly material. J. Water Process. Eng. 2018, 21, 44-51. [CrossRef]

95. Nassar, M.Y.; Abdelrahman, E.A.; Aly, A.A.; Mohamed, T.Y. A facile synthesis of mordenite zeolite nanostructures for efficient bleaching of crude soybean oil and removal of methylene blue dye from aqueous media. J. Mol. Liq. 2017, 248, 302-313. [CrossRef]

96. Zhao, Y.; Zhang, B.; Zhang, X.; Wang, J.; Liu, J.; Chen, R. Preparation of highly ordered cubic NaA zeolite from halloysite mineral for adsorption of ammonium ions. J. Hazard. Mater. 2010, 178, 658-664. [CrossRef]

97. Margeta, K.; Zabukovec, N.; Šiljeg, M.; Farkas, A. Natural Zeolites in Water Treatment-How Effective is Their Use. In Water Treatment; InTech: Rijeka, Croatia, 2013. [CrossRef]

98. Torabian, A.; Kazemian, H.; Seifi, L.; Bidhendi, G.N.; Azimi, A.A.; Ghadiri, S.K. Removal of Petroleum Aromatic Hydrocarbons by Surfactant-modified Natural Zeolite: The Effect of Surfactant. CLEAN-Soil Air Water 2010, 38, 77-83. [CrossRef]

99. Pandey, P.K.; Sharma, S.K.; Sambi, S.S. Removal of lead(II) from waste water on zeolite-NaX. J. Environ. Chem. Eng. 2015, 3, 2604-2610. [CrossRef]

100. Mohseni-Bandpi, A.; Al-Musawi, T.J.; Ghahramani, E.; Zarrabi, M.; Mohebi, S.; Vahed, S.A. Improvement of zeolite adsorption capacity for cephalexin by coating with magnetic $\mathrm{Fe}_{3} \mathrm{O}_{4}$ nanoparticles. J. Mol. Liq. 2016, 218, 615-624. [CrossRef]

101. Samarghandi, M.R.; Al-Musawi, T.J.; Mohseni-Bandpi, A.; Zarrabi, M. Adsorption of cephalexin from aqueous solution using natural zeolite and zeolite coated with manganese oxide nanoparticles. J. Mol. Liq. 2015, 211, 431-441. [CrossRef]

102. Gugushe, A.S.; Mpupaa, A.; Nomngongoabc, P.N. Ultrasound-assisted magnetic solid phase extraction of lead and thallium in complex environmental samples using magnetic multi-walled carbon nanotubes/zeolite nanocomposite. Microchem. J. 2019, 149, 103960. [CrossRef]

103. Nyankson, E.; Adjasoo, J.; Efavi, J.K.; Amedalor, R.; Yaya, A.; Manu, G.P.; Asare, K.; Amartey, N.A. Characterization and Evaluation of Zeolite $\mathrm{A} / \mathrm{Fe}_{3} \mathrm{O}_{4}$ Nanocomposite as a Potential Adsorbent for Removal of Organic Molecules from Wastewater. J. Chem. 2019, 2019, 1-13. [CrossRef]

104. Mao, N. Nonwoven fabric filters. In Advances in Technical Nonwovens; Kellie, G., Ed.; Woodhead Publishing: Cambridge, UK, 2016; pp. 273-310. [CrossRef]

105. Bowen, W.; Mukhtar, H. Characterisation and prediction of separation performance of nanofiltration membranes. J. Membr. Sci. 1996, 112, 263-274. [CrossRef]

106. Koyuncu, I.; Sengur, R.; Turken, T.; Guclu, S.; Pasaoglu, M. Advances in water treatment by microfiltration, ultrafiltration, and nanofiltration. In Advances in Membrane Technologies for Water Treatment; Woodhead Publishing: Oxford, UK, 2015; pp. 83-128. [CrossRef]

107. Charcosset, C. Some perspectives. In Membrane Processes in Biotechnology and Pharmaceutics; Elsevier: Amsterdam, The Netherlands, 2012; pp. 295-321. [CrossRef]

108. Nagy, E. Nanofiltration. In Basic Equations of Mass Transport Through a Membrane Layer; Elsevier: Amsterdam, The Netherlands, 2019; pp. 417-428.

109. Timmer, J.M.K. Properties of Nanofiltration Membranes: Model Development and Industrial Application. 2001.

110. Wu, L.; Wang, H.; Xu, T.-W.; Xu, Z.-L. Polymeric Membranes. In Membrane-Based Separations in Metallurgy; Elsevier: Amsterdam, The Netherlands, 2017; pp. 297-334. [CrossRef]

111. Mulyanti, R.; Susanto, H. Wastewater treatment by nanofiltration membranes. IOP Conf. Ser. Earth Environ. Sci. $2018,142$. [CrossRef]

112. Abdel-Fatah, M.A. Nanofiltration systems and applications in wastewater treatment: Review article. Ain Shams Eng. J. 2018, 9, 3077-3092. [CrossRef]

113. Thanuttamavong, M.; Yamamoto, K.; Oh, J.I.; Choo, K.H.; Choi, S.J. Rejection characteristics of organic and inorganic pollutants by ultra low-pressure nanofiltration of surface water for drinking water treatment. Desalination 2002, 145, 257-264. [CrossRef]

114. Shon, H.K.; Phuntsho, S.; Chaudhary, D.S.; Vigneswaran, S.; Cho, J. Nanofiltration for water and wastewater treatment-A mini review. Drink. Water Eng. Sci. 2013, 6, 47-53. [CrossRef]

115. Van Der Bruggen, B.; Hoek, E.M.; Tarabara, V.V. Nanofiltration. In Encyclopedia of Membrane Science and Technology; John Wiley \& Sons: Hoboken, NJ, USA, 2013; pp. 1-23.

116. Benfer, S.; Popp, U.; Richter, H.; Siewert, C.; Tomandl, G. Development and characterization of ceramic nanofiltration mem-branes. Sep. Purif. Technol. 2001, 22, 231-237. [CrossRef]

117. Mostafavi, S.; Mehrnia, M.; Rashidi, A. Preparation of nanofilter from carbon nanotubes for application in virus removal from water. Desalination 2009, 238, 271-280. [CrossRef]

118. Parham, H.; Bates, S.; Xia, Y.; Zhu, Y. A highly efficient and versatile carbon nanotube/ceramic composite filter. Carbon 2013, 54, 215-223. [CrossRef]

119. Han, Y.; Xu, Z.; Gao, C. Ultrathin Graphene Nanofiltration Membrane for Water Purification. Adv. Funct. Mater. 2013, 23, 3693-3700. [CrossRef]

120. Nair, R.R.; Wu, H.A.; Jayaram, P.N.; Grigorieva, I.V.; Geim, A.K. Unimpeded Permeation of Water Through Helium-Leak-Tight Graphene-Based Membranes. Science 2012, 335, 442-444. [CrossRef] [PubMed]

121. Saravanan, R.; Gracia, F.; Stephen, A. Basic Principles, Mechanism, and Challenges of Photocatalysis. In Nanocomposites for Visible Light-Induced Photocatalysis; Khan, M., Pradhan, D., Sohn, Y., Eds.; Springer: Cham, Switzerland, 2017; pp. 19-40. [CrossRef] 
122. Amano, F.; Nogami, K.; Abe, R.; Ohtani, B. Preparation and Characterization of Bismuth Tungstate Polycrystalline Flake-Ball Particles for Photocatalytic Reactions. J. Phys. Chem. C 2008, 112, 9320-9326. [CrossRef]

123. Malato, S.; Blanco, J.; Vidal, A.; Richter, C. Photocatalysis with solar energy at a pilot-plant scale: An overview. Appl. Catal. B Environ. 2002, 37, 1-15. [CrossRef]

124. Bethi, B.; Sonawane, S.H.; Bhanvase, B.A.; Gumfekar, S.P. Nanomaterials-based advanced oxidation processes for wastewater treatment: A review. Chem. Eng. Process. Process. Intensif. 2016, 109, 178-189. [CrossRef]

125. Rueda-Marquez, J.J.; Levchuk, I.; Fernández Ibañez, P.; Sillanpää, M. A critical review on application of photocatalysis for tox-icity reduction of real wastewaters. J. Clean. Prod. 2020, 258, 120694. [CrossRef]

126. Mehrjouei, M.; Müller, S.; Möller, D. A review on photocatalytic ozonation used for the treatment of water and wastewater. Chem. Eng. J. 2015, 263, 209-219. [CrossRef]

127. McLain, A.A. Photocatalytic Properties of Zinc Oxide and Graphene Nanocomposites. In Photocatalytic Properties of Zinc Oxide and Graphene Nanocomposites; Public Knowledge Project: Vancouver, BC, USA, 2019. [CrossRef]

128. Gómez-Pastora, J.; Dominguez, S.; Bringas, E.; Rivero, M.J.; Ortiz, I.; Dionysiou, D.D. Review and perspectives on the use of mag-netic nanophotocatalysts (MNPCs) in water treatment. Chem. Eng. J. 2017, 310, 407-427. [CrossRef]

129. Xu, P.; Zeng, G.M.; Huang, D.L.; Feng, C.L.; Hu, S.; Zhao, M.H.; Lai, C.; Wei, Z.; Huang, C.; Xie, G.X.; et al. Use of iron oxide nanomaterials in wastewater treatment: A review. Sci. Total Environ. 2012, 424, 1-10. [CrossRef]

130. Hot, J.; Topalov, J.; Ringot, E.; Bertron, A. Investigation on Parameters Affecting the Effectiveness of Photocatalytic Functional Coatings to Degrade NO: $\mathrm{TiO}_{2}$ Amount on Surface, Illumination, and Substrate Roughness. Int. J. Photoenergy 2017, $2017,1-14$. [CrossRef]

131. Herrmann, J.-M. Heterogeneous photocatalysis: Fundamentals and applications to the removal of various types of aqueous pollutants. Catal. Today 1999, 53, 115-129. [CrossRef]

132. Pirkanniemi, K.; Sillanpää, M. Heterogeneous water phase catalysis as an environmental application: A review. Chemosphere 2002, 48, 1047-1060. [CrossRef]

133. Colmenares, J.C.; Luque, R.; Campelo, J.M.; Colmenares, F.; Karpiński, Z.; Romero, A.A. Nanostructured Photocatalysts and Their Applications in the Photocatalytic Transformation of Lignocellulosic Biomass: An Overview. Materials 2009, 2, $2228-2258$. [CrossRef]

134. Bai, L.; Wei, M.; Hong, E.; Shan, D.; Liu, L.; Yang, W.; Tang, X.; Wang, B. Study on the controlled synthesis of Zr/TiO $2 /$ SBA-15 nanophotocatalyst and its photocatalytic performance for industrial dye reactive red X-3B. Mater. Chem. Phys. 2020, $246,122825$. [CrossRef]

135. Mahmoudian-Boroujerd, L.; Karimi-Jashni, A.; Hosseini, S.N.; Paryan, M. Optimization of rDNA degradation in recombinant Hepatitis B vaccine production plant wastewater using visible light excited Ag-doped $\mathrm{TiO}_{2}$ nanophotocatalyst. Process. Saf. Environ. Prot. 2019, 122, 328-338. [CrossRef]

136. Malakootian, M.; Nasiri, A.; Asadipour, A.; Faraji, M.; Kargar, E. A facile and green method for synthesis of $\mathrm{ZnFe}_{2} \mathrm{O}_{4} @ \mathrm{CMC}$ as a new magnetic nanophotocatalyst for ciprofloxacin removal from aqueous media. MethodsX 2019, 6, 1575-1580. [CrossRef]

137. Karimi, H.; Rajabi, H.R.; Kavoshi, L. Application of decorated magnetic nanophotocatalysts for efficient photodegradation of organic dye: A comparison study on photocatalytic activity of magnetic zinc sulfide and graphene quantum dots. J. Photochem. Photobiol. A Chem. 2020, 397, 112534. [CrossRef]

138. Yosefi, L.; Haghighi, M.; Allahyari, S. Solvothermal synthesis of flowerlike p-BiOI/n- $\mathrm{ZnFe}_{2} \mathrm{O}_{4}$ with enhanced visible light driven nanophotocatalyst used in removal of acid orange 7 from wastewater. Sep. Purif. Technol. 2017, 178, 18-28. [CrossRef]

139. Margan, P.; Haghighi, M. Sono-coprecipitation synthesis and physicochemical characterization of CdO-ZnO nanophoto-catalyst for removal of acid orange 7 from wastewater. Ultrason. Sonochem. 2018, 40, 323-332. [CrossRef]

140. Wang, W.; Zhou, C.; Yang, Y.; Zeng, G.; Zhang, C.; Zhou, Y.; Yang, J.; Huang, D.; Wang, H.; Xiong, W.; et al. Carbon nitride based photocatalysts for solar photocatalytic disinfection, can we go further? Chem. Eng. J. 2021, 404, 126540. [CrossRef]

141. Montgomery, M.A.; Elimelech, M. Water And Sanitation in Developing Countries: Including Health in the Equation. Environ. Sci. Technol. 2007, 41, 17-24. [CrossRef] [PubMed]

142. Zhang, C.; Li, Y.; Zhang, W.; Wang, P.; Wang, C. Metal-free virucidal effects induced by g-C3N4 under visible light irradiation: Statistical analysis and parameter optimization. Chemosphere 2018, 195, 551-558. [CrossRef]

143. Rikta, S.Y. Application of Nanoparticles for Disinfection and Microbial Control of Water and Wastewater. In Nanotechnology in Water and Wastewater Treatment; Elsevier: Amsterdam, The Netherlands, 2019; pp. 159-176. [CrossRef]

144. Van Asselt, A.; Te Giffel, M.C. Pathogen resistance and adaptation to disinfectants and sanitisers. In Understanding Pathogen Behaviour; Elsevier: Amsterdam, The Netherlands, 2005; pp. 484-506.

145. Yao, B.; Luo, Z.; Xiong, W.; Song, B.; Zeng, Z.; Zhou, Y. Disinfection techniques of human norovirus in municipal wastewater: Challenges and future perspectives. Curr. Opin. Environ. Sci. Health 2020. [CrossRef]

146. Zhao, J.; Yan, P.; Snow, B.; Santos, R.M.; Chiang, Y.W. Micro-structured copper and nickel metal foams for wastewater disinfection: Proof-of-concept and scale-up. Process. Saf. Environ. Prot. 2020, 142, 191-202. [CrossRef] [PubMed]

147. Zhang, T.; Yu, H.; Li, J.; Song, H.; Wang, S.; Zhang, Z.; Chen, S. Green light-triggered antimicrobial cotton fabric for wastewater disinfection. Mater. Today Phys. 2020, 15, 100254. [CrossRef] 
148. Qin, L.; Zeng, Z.; Zeng, G.; Lai, C.; Duan, A.; Xiao, R.; Huang, D.; Fu, Y.; Yi, H.; Li, B.; et al. Cooperative catalytic performance of bimetallic Ni-Au nanocatalyst for highly efficient hydrogenation of nitroaromatics and corresponding mechanism insight. Appl. Catal. B Environ. 2019, 259, 118035. [CrossRef]

149. Liu, Y.; Zeng, G.; Zhong, H.; Wang, Z.; Liu, Z.; Cheng, M.; Liu, G.; Yang, X.; Liu, S. Effect of rhamnolipid solubilization on hexadecane bioavailability: Enhancement or reduction? J. Hazard. Mater. 2017, 322, 394-401. [CrossRef]

150. Zhang, C.; Lai, C.; Zeng, G.; Huang, D.; Yang, C.; Wang, Y.; Zhou, Y.; Cheng, M. Efficacy of carbonaceous nanocomposites for sorbing ionizable antibiotic sulfamethazine from aqueous solution. Water Res. 2016, 95, 103-112. [CrossRef]

151. Guidetti, G.; Giuri, D.; Zanna, N.; Calvaresi, M.; Montalti, M.; Tomasini, C. Biocompatible and Light-Penetrating Hydrogels for Water Decontamination. ACS Omega 2018, 3, 8122-8128. [CrossRef]

152. Xiu, Z.-M.; Zhang, Q.-B.; Puppala, H.L.; Colvin, V.L.; Alvarez, P.J.J. Negligible Particle-Specific Antibacterial Activity of Silver Nanoparticles. Nano Lett. 2012, 12, 4271-4275. [CrossRef]

153. Ivanova, E.P.; Hasan, J.; Webb, H.K.; Vervinskas, G.; Juodkazis, S.; Truong, V.K.; Wu, A.H.; Lamb, R.N.; Baulin, V.A.; Watson, G.S.; et al. Bactericidal activity of black silicon. Nat. Commun. 2013, 4, 2838. [CrossRef]

154. Zhang, D.; Li, G.; Yu, J.C. Inorganic materials for photocatalytic water disinfection. J. Mater. Chem. 2010, 20, 4529-4536. [CrossRef]

155. Wang, H.; Zhou, Y.; Jiang, X.; Sun, B.; Zhu, Y.; Wang, H.; Su, Y.; He, Y. Simultaneous Capture, Detection, and Inactivation of Bacteria as Enabled by a Surface-Enhanced Raman Scattering Multifunctional Chip. Angew. Chem. Int. Ed. 2015, 54, 5132-5136. [CrossRef]

156. Mauter, M.S.; Zucker, I.; Perreault, F.; Werber, J.R.; Kim, J.H.; Elimelech, M. The role of nanotechnology in tackling global water challenges. Nat. Sustain. 2018, 1, 166-175. [CrossRef]

157. Moustafa, M.T. Removal of pathogenic bacteria from wastewater using silver nanoparticles synthesized by two fungal species. Water Sci. 2017, 31, 164-176. [CrossRef]

158. Ahamed, M.; Alhadlaq, H.; Khan, M.A.M.; Karuppiah, P.; Al-Dhabi, N.A. Synthesis, Characterization, and Antimicrobial Activity of Copper Oxide Nanoparticles. J. Nanomater. 2014, 2014, 1-4. [CrossRef]

159. Li, Q.; Mahendra, S.; Lyon, D.Y.; Brunet, L.; Liga, M.V.; Li, D.; Alvarez, P.J. Antimicrobial nanomaterials for water disinfection and microbial control: Potential applications and implications. Water Res. 2008, 42, 4591-4602. [CrossRef]

160. Mustapha, S.; Ndamitso, M.M.; Abdulkareem, A.S.; Tijani, J.O.; Shuaib, D.T.; Ajala, A.O.; Mohammed, A.K. Application of TiO2 and $\mathrm{ZnO}$ nanoparticles immobilized on clay in wastewater treatment: A review. Appl. Water Sci. 2020, 10, 49. [CrossRef]

161. Liu, X.; Wang, M.; Zhang, S.; Pan, B. Application potential of carbon nanotubes in water treatment: A review. J. Environ. Sci. 2013, 25, 1263-1280. [CrossRef]

162. Elmi, F.; Alinezhad, H.; Moulana, Z.; Salehian, F.; Tavakkoli, S.M.; Asgharpour, F.; Fallah, H.; Elmi, M.M. The use of antibacterial activity of $\mathrm{ZnO}$ nanoparticles in the treatment of municipal wastewater. Water Sci. Technol. 2014, 70, 763-770. [CrossRef]

163. Edwards-Jones, V. The benefits of silver in hygiene, personal care and healthcare. Lett. Appl. Microbiol. 2009, 49, 147-152. [CrossRef]

164. Durán, N.; Marcato, P.D.; Alves, O.L.; Souza, G.I.H.D.; Esposito, E. Mechanistic aspects of biosynthesis of silver nanoparticles by several Fusarium oxysporum strains. J. Nanobiotechnol. 2005, 3, 8. [CrossRef] [PubMed]

165. Das, S.; Ranjana, N.; Misra, A.J.; Suar, M.; Mishra, A.; Tamhankar, A.J.; Lundborg, C.S.; Tripathy, S.K. Disinfection of the Water Borne Pathogens Escherichia coli and Staphylococcus aureus by Solar Photocatalysis Using Sonochemically Synthesized Reusable Ag@ZnO Core-Shell Nanoparticles. Int. J. Environ. Res. Public Health 2017, 14, 747. [CrossRef] [PubMed]

166. Schmidt-Mende, L.; MacManus-Driscoll, J.L. ZnO—Nanostructures, defects, and devices. Mater Today 2007, 10, 40-48. [CrossRef]

167. Wong, K.-A.; Lam, S.-M.; Sin, J.-C. Wet chemically synthesized ZnO structures for photodegradation of pre-treated palm oil mill effluent and antibacterial activity. Ceram. Int. 2019, 45, 1868-1880. [CrossRef]

168. Jin, S.-E.; Jin, J.E.; Hwang, W.; Hong, S.W. Photocatalytic antibacterial application of zinc oxide nanoparticles and self-assembled networks under dual UV irradiation for enhanced disinfection. Int. J. Nanomed. 2019, 14, 1737-1751. [CrossRef]

169. Gul, S.; Khan, S.A.; Rehan, Z.A.; Akhtar, K.; Khan, M.A.; Khan, M.I.; Rashid, M.I.; Asiri, A.M.; Khan, S.B. Antibacterial CuO-PES$\mathrm{CA}$ nancomposite membranes supported $\mathrm{Cu} 0$ nanoparticles for water permeability and reduction of organic pollutants. J. Mater. Sci. Mater. Electron. 2019, 30, 10835-10847. [CrossRef]

170. He, X.; Yang, D.P.; Zhang, X.; Liu, M.; Kang, Z.; Lin, C.; Jia, N.; Luque, R. Waste eggshell membrane-templated CuO-ZnO nanocomposites with enhanced adsorption, catalysis and antibacterial properties for water purification. Chem. Eng. J. 2019, 369, 621-633. [CrossRef]

171. Singh, H.; Bamrah, A.; Bhardwaj, S.K.; Deep, A.; Khatri, M.; Kim, K.-H.; Bhardwaj, N. Nanomaterial-based fluorescent sensors for the de-tection of lead ions. J. Hazard. Mater. 2020, 407, 124379. [CrossRef]

172. Vikesland, P.J. Nanosensors for water quality monitoring. Nat. Nanotechnol. 2018, 13, 651-660. [CrossRef]

173. Bhattacharyya, S.; Bennett, J.; Short, L.C.; Theisen, T.S.; Wichman, M.D.; White, J.C.; Wright, S. Nanotechnology in the Water Industry, Part 1: Occurrence and Risks. J. Am. Water Work. Assoc. 2017, 109, 30-37. [CrossRef]

174. Farahi, R.H.; Passian, A.; Tetard, L.; Thundat, T. Critical Issues in Sensor Science to Aid Food and Water Safety. ACS Nano 2012, 6, 4548-4556. [CrossRef]

175. Graboski, A.M.; Martinazzo, J.; Ballen, S.C.; Steffens, J.; Steffens, C. Nanosensors for water quality control. In Nanotechnology in the Beverage Industry; Elsevier: Amsterdam, The Netherlands, 2020; pp. 115-128. [CrossRef] 
176. Scoville, S. Implications of Nanotechnology Safety of Sensors on Homeland Security Industries. In Nanotechnology Safety; Elsevier: Amsterdam, The Netherlands, 2013; pp. 175-194. [CrossRef]

177. Kurbanoglu, S.; Ozkan, S.A. Electrochemical carbon based nanosensors: A promising tool in pharmaceutical and biomedical analysis. J. Pharm. Biomed. Anal. 2018, 147, 439-457. [CrossRef]

178. Vikesland, P.J.; Wigginton, K.R. Nanomaterial Enabled Biosensors for Pathogen Monitoring-A Review. Environ. Sci. Technol. 2010, 44, 3656-3669. [CrossRef]

179. Riquelme, M.V.; Leng, W.; Carzolio, M.; Pruden, A.; Vikesland, P. Stable oligonucleotide-functionalized gold nanosensors for environmental biocontaminant monitoring. J. Environ. Sci. 2017, 62, 49-59. [CrossRef]

180. Talari, F.F.; Bozorg, A.; Faridbod, F.; Vossoughi, M. A novel sensitive aptamer-based nanosensor using rGQDs and MWCNTs for rapid detection of diazinon pesticide. J. Environ. Chem. Eng. 2021, 9, 104878. [CrossRef]

181. Atar, N.; Eren, T.; Yola, M.L.; Wang, S. A sensitive molecular imprinted surface plasmon resonance nanosensor for selective determination of trace triclosan in wastewater. Sens. Actuators B Chem. 2015, 216, 638-644. [CrossRef]

182. Hu, R.; Tang, R.; Xu, J.; Lu, F. Chemical nanosensors based on molecularly-imprinted polymers doped with silver nanoparticles for the rapid detection of caffeine in wastewater. Anal. Chim. Acta 2018, 1034, 176-183. [CrossRef]

183. Zhang, S.; Jin, L.; Liu, J.; Wang, Q.; Jiao, L. A label-free yellow-emissive carbon dot-based nanosensor for sensitive and selective ratiometric detection of chromium (VI) in environmental water samples. Mater. Chem. Phys. 2020, 248, 122912. [CrossRef]

184. Westerhoff, P.; Alvarez, P.; Li, Q.; Gardea-Torresdey, J.; Zimmerman, J. Overcoming implementation barriers for nanotechnology in drinking water treatment. Environ. Sci. Nano. R. Soc. Chem. 2016, 3, 1241-1253. [CrossRef]

185. Mazhar, M.A.; Khan, N.A.; Ahmed, S.; Khan, A.H.; Hussain, A.; Changani, F.; Yousefi, M.; Ahmadi, S.; Vambol, V. Chlorination disinfection by-products in mu-nicipal drinking water-A review. J. Clean. Prod. 2020, 273, 123159. [CrossRef]

186. Pardhi, V.P.; Verma, T.; Flora, S.; Chandasana, H.; Shukla, R. Nanocrystals: An Overview of Fabrication, Characterization and Therapeutic Applications in Drug Delivery. Curr. Pharm. Des. 2019, 24, 5129-5146. [CrossRef]

187. Raza, M.; Kanwal, Z.; Rauf, A.; Sabri, A.; Riaz, S.; Naseem, S. Size- and Shape-Dependent Antibacterial Studies of Silver Na-noparticles Synthesized by Wet Chemical Routes. Nanomaterials 2016, 6, 74. [CrossRef] [PubMed]

188. Sukhanova, A.; Bozrova, S.; Sokolov, P.; Berestovoy, M.; Karaulov, A.; Nabiev, I. Dependence of Nanoparticle Toxicity on Their Physical and Chemical Properties. Nanoscale Res. Lett. 2018, 13, 1-21. [CrossRef] [PubMed]

189. Anand, A.; Rajchakit, U.; Sarojini, V. Detection and removal of biological contaminants in water. In Nanomaterials for the Detection and Removal of Wastewater Pollutants; Elsevier: Amsterdam, The Netherlands, 2020; pp. 69-110. [CrossRef]

190. Pan, Y.; Liu, X.; Zhang, W.; Liu, Z.; Zeng, G.; Shao, B.; Liang, Q.; He, Q.; Yuan, X.; Huang, D.; et al. Advances in photocatalysis based on fullerene C60 and its derivatives: Properties, mechanism, synthesis, and applications. Appl. Catal. B Environ. 2020, 265, 118579. [CrossRef]

191. Kokkinos, P.; Mantzavinos, D.; Venieri, D. Current trends in the application of nanomaterials for the removal of emerging micropollutants and pathogens from water. Molecules 2020, 25, 2016. [CrossRef]

192. Westerhoff, P.K.; Kiser, M.A.; Hristovski, K. Nanomaterial Removal and Transformation During Biological Wastewater Treatment. Environ. Eng. Sci. 2013, 30, 109-117. [CrossRef]

193. Robichaud, C.O.; Uyar, A.E.; Darby, M.R.; Zucker, L.G.; Wiesner, M.R. Estimates of upper bounds and trends in nano-TiO2 pro-duction as a basis for exposure assessment. Environ. Sci. Technol. 2009, 43, 4227-4233. [CrossRef]

194. Kim, E.; Kim, S.-H.; Kim, H.-C.; Lee, S.G.; Lee, S.J.; Jeong, S.W. Growth inhibition of aquatic plant caused by silver and titanium oxide nanoparticles. Toxicol. Environ. Health Sci. 2011, 3, 1-6. [CrossRef]

195. Abramenko, N.B.; Demidova, T.B.; Abkhalimov, V.; Ershov, B.G.; Krysanov, E.Y.; Kustov, L.M. Ecotoxicity of different-shaped silver nanoparticles: Case of zebrafish embryos. J. Hazard. Mater. 2018, 347, 89-94. [CrossRef]

196. Albukhari, S.M.; Ismail, M.; Akhtar, K.; Danish, E.Y. Catalytic reduction of nitrophenols and dyes using silver nanoparticles @ cellulose polymer paper for the resolution of waste water treatment challenges. Coll. Surf. A Physicochem. Eng. Asp. 2019, 577, 548-561. [CrossRef]

197. De Matteis, V.; Rinaldi, R. Toxicity Assessment in the Nanoparticle Era. In Cellular and Molecular Toxicology of Nanoparticles; Springer: Cham, Switzerland, 2018; pp. 1-19. [CrossRef]

198. Cimbaluk, G.V.; Ramsdorf, W.A.; Perussolo, M.C.; Santos, H.K.F.; Da Silva De Assis, H.C.; Schnitzler, M.C.; Schnitzler, D.C.; Carneiro, P.G.; Cestari, M.M. Evaluation of mul-tiwalled carbon nanotubes toxicity in two fish species. Ecotoxicol. Environ. Saf. 2018, 150, 215-223. [CrossRef]

199. Khan, M.S.; Qureshi, N.A.; Jabeen, F. Assessment of toxicity in fresh water fish Labeo rohita treated with silver nanoparticles. Appl. Nanosci. 2017, 7, 167-179. [CrossRef]

200. Das, R.; Leo, B.F.; Murphy, F. The Toxic Truth About Carbon Nanotubes in Water Purification: A Perspective View. Nanoscale Res. Lett. 2018, 13, 1-10. [CrossRef] 